\title{
Patient-Derived Induced Pluripotent Stem Cells (iPSCs) and Cerebral Organoids for Drug Screening and Development in Autism Spectrum Disorder: Opportunities and Challenges
}

\author{
Chiara Villa *(D), Romina Combi (D), Donatella Conconi (D) and Marialuisa Lavitrano *(D)
}

School of Medicine and Surgery, University of Milano-Bicocca, 20900 Monza, Italy; romina.combi@unimib.it (R.C.); donatella.conconi@unimib.it (D.C.)

* Correspondence: chiara.villa@unimib.it (C.V.); marialuisa.lavitrano@unimib.it (M.L.); Tel.: +39-02-6448-8138 (C.V.); +39-02-6448-8336 (M.L.)

\section{check for}

updates

Citation: Villa, C.; Combi, R.;

Conconi, D.; Lavitrano, $\mathrm{M}$.

Patient-Derived Induced Pluripotent

Stem Cells (iPSCs) and Cerebral

Organoids for Drug Screening and

Development in Autism Spectrum

Disorder: Opportunities and

Challenges. Pharmaceutics 2021, 13,

280. https://doi.org/10.3390/

pharmaceutics 13020280

Academic Editor: Nunzio Denora

Received: 29 January 2021

Accepted: 17 February 2021

Published: 19 February 2021

Publisher's Note: MDPI stays neutral with regard to jurisdictional claims in published maps and institutional affiliations.

Copyright: (c) 2021 by the authors. Licensee MDPI, Basel, Switzerland. This article is an open access article distributed under the terms and conditions of the Creative Commons Attribution (CC BY) license (https:/ / creativecommons.org/licenses/by/ $4.0 /)$.
Abstract: Autism spectrum disorder (ASD) represents a group of neurodevelopmental diseases characterized by persistent deficits in social communication, interaction, and repetitive patterns of behaviors, interests, and activities. The etiopathogenesis is multifactorial with complex interactions between genetic and environmental factors. The clinical heterogeneity and complex etiology of this pediatric disorder have limited the development of pharmacological therapies. The major limit to ASD research remains a lack of relevant human disease models which can faithfully recapitulate key features of the human pathology and represent its genetic heterogeneity. Recent advances in induced pluripotent stem cells (iPSCs), reprogrammed from somatic cells of patients into all types of patientspecific neural cells, have provided a promising cellular tool for disease modeling and development of novel drug treatments. The iPSCs technology allowed not only a better investigation of the disease etiopathogenesis but also opened up the potential for personalized therapies and offered new opportunities for drug discovery, pharmacological screening, and toxicity assessment. Moreover, iPSCs can be differentiated and organized into three-dimensional (3D) organoids, providing a model which mimics the complexity of the brain's architecture and more accurately recapitulates tissue- and organ-level disease pathophysiology. The aims of this review were to describe the current state of the art of the use of human patient-derived iPSCs and brain organoids in modeling ASD and developing novel therapeutic strategies and to discuss the opportunities and major challenges in this rapidly moving field.

Keywords: autism spectrum disorders; induced pluripotent stem cells; brain organoids

\section{Introduction}

Over the past decade, the development of induced pluripotent stem cell (iPSC) technology has provided a novel means to generate disease-relevant cells for in vitro investigation of the molecular and cellular mechanisms underpinning human complex disorders [1,2]. Diseases affecting the central nervous system (CNS) have been the most frequent targets, given the limited access to vital human brain cells and to the lack of or adequacy of existing animal models [3]. iPSCs are undifferentiated cells with self-renewal capability and can be directly generated from somatic cells (isolated from the skin, blood, or urine of an individual) by expressing the reprogramming factors Oct4, Sox2, Klf4, and c-Myc [4]. In principle, the resulting patient-specific iPSCs can subsequently differentiate into diseaserelevant cell types, including multiple subclasses of neurons, astrocytes, and microglia, thus providing an unlimited source of cells that harbor the patient's precise genome associated with the pathogenesis in the appropriate microenvironment. Therefore, the use of iPSCs offers opportunity to study CNS disorders overcoming the ethical limits of human embryonic stem cells (hESCs) or limited durability of primary cultures [5]. Recapitulating disease features, these cells can serve as large-scale drug screening platforms for novel 
therapeutic targets and have the great potential to be used in cell therapy and personalized medicine as compared to different sources of stem cell, such as hESCs or mesenchymal stem cells (MSCs). Main advantages and disadvantages of these stem cell types are briefly summarized in Table 1.

Table 1. Main advantages and disadvantages of different types of stem cells: ESCs, MSCs, and iPSCs.

\begin{tabular}{|c|c|c|}
\hline Cell Types & Advantages & Disadvantages \\
\hline ESCs & $\begin{array}{l}\text { Low cost } \\
\text { Established protocols for maintenance in culture } \\
\text { Any cell type differentiation (pluripotency) } \\
\text { Efficient differentiation }\end{array}$ & $\begin{array}{c}\text { Mutation rate } \\
\text { Embryo destruction } \\
\text { Ethical/political concerns } \\
\text { Difficulty to obtain } \\
\text { Lack of genetic/immunohistocompatibility match }\end{array}$ \\
\hline MSCs & $\begin{array}{c}\text { Availability } \\
\text { Ease to isolate and expand } \\
\text { No ethical concerns } \\
\text { Trans-differentiation capacities } \\
\text { Success in various clinical applications }\end{array}$ & $\begin{array}{l}\text { Limited number of cell type differentiation (multipotency) } \\
\text { Loss of proliferative and differentiation capacities over } \\
\text { continuous passages } \\
\text { Standardization difficulty } \\
\text { Genetic heterogeneity }\end{array}$ \\
\hline iPSCs & $\begin{array}{c}\text { No ethical concerns } \\
\text { Ease to obtain } \\
\text { Use of abundant somatic cells of donor } \\
\text { Any cell type differentiation (pluripotency) } \\
\text { Genetic/immunohistocompatibility match } \\
\text { Utility for drug development and developmental } \\
\text { studies }\end{array}$ & $\begin{array}{c}\text { Cost of production } \\
\text { Difficulty of standardization, reproducibility and } \\
\text { maintenance } \\
\text { Tumorigenesis } \\
\text { Genomic instability }\end{array}$ \\
\hline
\end{tabular}

ESCs, embryonic stem cells; MSCs, mesenchymal stem cells; iPSCs: induced pluripotent stem cells.

Although iPSCs-based two-dimensional (2D) brain cultures have increased the understanding of different diseases, human pathologies originate in the context of complex interactions at the cellular, tissue and organ levels. To overcome the inherent constraints associated to iPSCs-derived 2D cultures, three-dimensional (3D) models have been recently implemented, leading to the generation of cerebral organoids, a complex self-organizing 3D aggregate of different cell types derived from iPSCs [6]. Brain organoids possess cerebrallike structures, thus mimicking more closely the in vivo human pathophysiology [7].

Autism spectrum disorder (ASD) encompasses a broad range of complex polygenic and multifactorial neurodevelopmental diseases diagnosed in early childhood (as young as 18 months of age), affecting social interaction, communication, interests, and behavior [8]. The worldwide prevalence of ASD is just under $1 \%$ in children with higher estimates in high-income countries and has markedly increased in the last decade probably due to rising awareness of the condition and improved criteria for diagnosis [9]. The core symptoms of ASD vary in degree of severity and are often accompanied by other concomitant diseases and conditions, including epilepsy, anxiety, obsessive compulsive disorder, intellectual disability, schizophrenia (SZ), and attention-deficit hyperactivity disorder (ADHD) [10,11]. Because of the heterogeneity of symptoms and severity of ASD, the disorder may be diagnosed in children at different ages [12]. Most children who are diagnosed with ASD at less than 3 years have retained their diagnosis, while approximately $9 \%$ of children who are diagnosed with ASD in early childhood may not meet criteria for ASD by young adulthood [12]. While its exact etiology remains unclear, ASD is known to have a strong genetic background, with family and twins studies suggesting a sizable heritability ranging from 50 to $90 \%$ [13-15]. The clinical heterogeneity of ASD is due to several factors: the complexity of its genetic profile (the involvement of multiple genes and the existence of different inheritance patterns); the existence of gene-environment interactions; the diverse nature genetic variants involved (ranging from common, rare, de novo and inherited in both coding and non-coding regions of the genome) $[16,17]$. ASD has been typically classified into non-syndromic (idiopathic, unknown genetic etiology) and syndromic (caused by a known genetic defect), based on a lack of or association to clinical manifestations outside 
of the autistic features, respectively $[18,19]$. In the "omics" era, the terms "syndromic" versus "non-syndromic" ASD fare slightly better under careful scrutiny and could be used with appropriate caveats. The use of this classification based on clinical observation demonstrated that it could led to erroneous conclusions that might be corrected retrospectively by means of "omic" studies. For example, rare syndromic mutations were reported in individuals with ASD who were thought not to have syndromic features based on a clinical exam, and, conversely, syndromic features became apparent only by a re-categorization of non-syndromic cohorts after genetic evaluation. Recently, it has become clear that a considerable overlap exists between molecular pathways and biological mechanisms detected in syndromic versus non-syndromic ASD. The term syndromic would be better substituted with "associated with known medical or genetic condition". Nonetheless, in the description of studies on iPSCs and organoids, we will use the classical classification in syndromic and non-syndromic considering that the cited literature is based on these two groups. In the Supplementary Table S1 resuming the main ASD-associated syndromes, we properly used a classification of syndromic ASD based on the genetic etiology of each disease (monogenic vs. chromosomal disorders; Table S1).

Several autism-susceptibility or genetic risk factors identified in syndromic forms of ASDs involved genes with a role in different processes: the regulation of synaptic plasticity, cell adhesion, neural connectivity, dendritic trafficking, transcription, gene imprinting, chromatin remodeling, and neurotransmission [20-24]. Moreover, modifying risk factors contribute in delineating the observed phenotype. These factors include several pre- and postnatal environmental factors, including maternal smoking, parental age of birth, infection, alcohol consumption, pollution, pesticide exposure, and gestational complications, such as bleeding or diabetes [25-29].

As the multigenic origin of idiopathic ASD makes it difficult to model, iPSCs-based technologies from individuals with genetically complex etiologies have enabled the investigation of pathological mechanisms in disease-relevant human brain cell types and therefore offer a promising platform to test drugs in a safe environment with human genetic background and relevance [30]. Herein, we report advances in modeling ASD with iPSCs-derived technologies and their use in the drug discovery and the development of potential new treatments, as well as their relevance in clinical applications and precision medicine approaches (Figure 1). Moreover, we discuss the challenges of these models. 


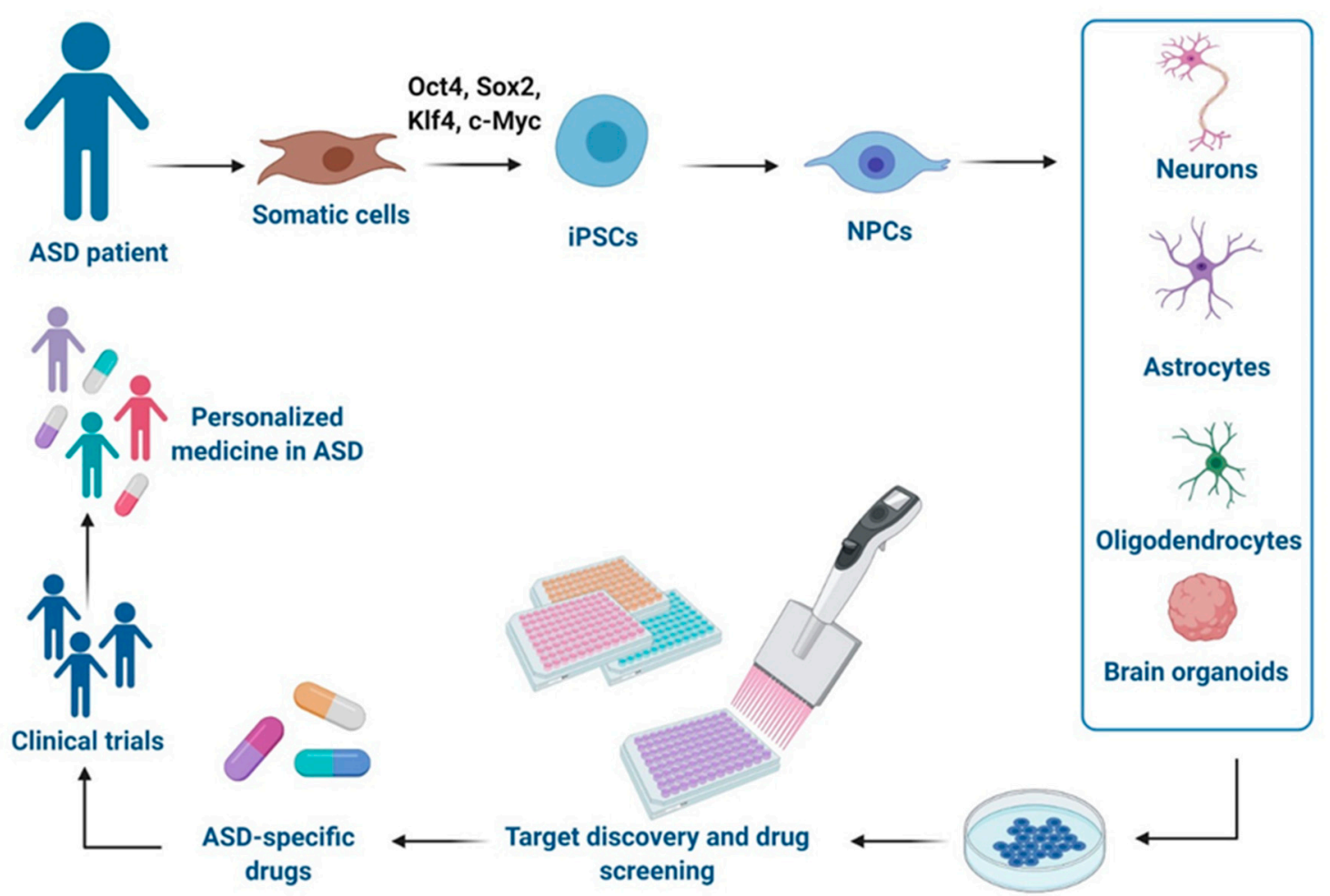

Figure 1. Schematic representation of disease modeling and drug discovery with iPSCs in Autism spectrum disorder (ASD). Specific iPSCs can be derived from somatic cells of ASD individuals and can be further differentiated into different cells types of the central nervous system (CNS) or organized in brain organoids for drug discovery in vitro, development of new drugs, and clinical trials, leading to a personalized medicine for ASD. This figure was created with BioRender.com (accessed on 11 February 2021).

\section{2. iPSC Models of ASDs}

The iPSC technology has led to insight into relevant cell types involved in disease mechanisms of ASD, offering a ground-breaking platform to study abnormalities in neurodevelopmental processes that can functionally alter neural circuitry [31]. The majority of iPSCs disease modeling studies use the conventional 2D monolayer culture models to recreate disease-relevant cell types. Two different main strategies are used for producing neural cell starting form iPSCs: the direct differentiation or the reprogramming. In the first case, iPSCs are firstly induced to neural progenitor cells (NPCs) and then differentiated by exposition to trophic factors (e.g., cAMP, BDNF, NT3, and GDNF) [32]. In the reprogramming strategy, iPSCs are transduced with lentiviruses carrying specific transcription factors and an antibiotic selection cassette for efficient conversion and selection [33]. Each strategy shows some advantages and disadvantages compared to the other and their choice is strongly related with the laboratory preference. Different iPSCs-derived phenotypes in NPCs, neurons and glial cells (mainly astrocytes and oligodendrocytes) have been already described for both non-syndromic and syndromic forms of ASD.

\section{1. iPSCs-Derived Neural Progenitor Cells}

NPCs are a population of cells with self-renewal and multipotent differentiation ability that can differentiate into both mature neurons and glial cells. NPCs play an important role in neurogenesis [34], and their dysfunction has been related with both nonsyndromic [35-38] and syndromic ASD, including RETT syndrome (RTT) [39-42], Fragile X syndrome (FXS) [43,44], tuberous sclerosis complex (TSC) [45,46], Phelan-McDermid syndrome (PMDS) [47], and Timothy syndrome (TS) [48,49]. 
In regard to idiopathic ASD, NPCs from individuals with macrocephaly displayed an increased cellular proliferation resulted from alterations in a canonical Wnt- $\beta$-catenin/BRN transcriptional cascade [35]. These abnormalities in proliferation lead to aberrant neurogenesis and reduced synaptogenesis, thus contributing to functional defects in neuronal networks [35]. Consistently, a recent study demonstrated that the hyperproliferation observed in NPCs derived from iPSCs of ASD subjects with macrocephaly affects genome instability by inducing replication stress-associated genes [36]. Other authors reported that iPSCs-derived NPCs show an impaired crosstalk between the pathways of mTORC1 and Reelin-DAB1, which is known to play a crucial role in regulating neuronal migration and synapse function [37]. This altered interplay was already shown to affect neuronal migration and positioning in a TSC mouse model and in cortical tubers from TSC patients [50]. Moreover, abnormalities in neuronal development, morphology and function were observed in NPCs from a non-syndromic ASD child with a de novo balanced translocation disrupting TRPC6, encoding for the human transient receptor potential 6 channel, involved in excitatory synapse and dendritic spine formation [38].

NPCs were also obtained from patients affected by RTT (OMIM \#312750), an earlyonset neurodevelopmental disorder caused by mutations in the $\mathrm{X}$-linked gene methylCpG-binding protein 2 (MECP2; Xp28), a ubiquitously expressed transcriptional regulator essential for the maturation and normal function of neurons [51,52]. This syndrome is the second most common cause of severe intellectual disability in females and, a considerable fraction of affected individuals meets diagnostic criteria for ASD [53]. Atypical RTT variants have been identified, associated with mutations in cyclin-dependent kinase-like 5 (CDKL5; Xp22.13) and forkhead box protein G1 (FOXG1; 14q12) [51]. NPCs derived from iPSCs of patients carrying different MECP2 mutations underwent X-inactivation when differentiating into functional neurons [39]. Another study found an increase in neural long-interspersed nuclear element-1 (LINE-1) retrotransposon, suggesting that MECP2 is involved in its mobility within the CNS [40]. In three children with MECP2 duplication, an altered expression of neuronal progenitor genes in NPCs was found [41]. Interestingly, a recent report demonstrated that NPCs and also cortical neurons show a global repressed translation and a decreased ribosome engagement of NEDD4-family ubiquitin ligases, leading to accumulation of target proteins that escape proteasome degradation. These evidences provide insight into novel therapeutic strategies based on the regulation of ubiquination process [42].

FXS (OMIM \#300624) is responsible for the most common monogenic cause of ASD that is typically due to a triplet repeat expansion (>200 CGG repeats in the $5^{\prime}$ untranslated region) and subsequent methylation of the FMR1 gene on the $X$ chromosome ( $\mathrm{Xq27.3)} \mathrm{[54].} \mathrm{As}$ a result, the amount of FMRP (protein product of FMR1) decreases, leading to an abnormal translation of different proteins. In fact, FMRP is an mRNA binding protein that regulates the mRNA transport and translational regulation in dendrites [54]. In the case of FXS, Telias et al. performed directed differentiation of cells from three patients and observed in FXS neural progenitors an abnormal expression of key NPC genes (SOX1, NOTCH1, PAX6) [43]. The iPSCs-derived FXS NPCs were then used to investigate functional maturation of the excitatory transmission system in response to the glutamate analog (AMPA) [44]. The authors demonstrated an impairment in calcium $\left(\mathrm{Ca}^{2+}\right)$ signaling via AMPA receptors (AMPARs), suggesting that their functional alterations affect neuronal differentiation and contribute to aberrant neuronal circuit formation and function in FXS [44].

Another ASD-associated syndrome where iPSCs were obtained and studied is TSC (OMIM \#191100 and \#613254), an autosomal dominant genetic disorder, characterized by benign tumors in the brain and other organs, epilepsy, cognitive impairment, and high penetrance of ASD [55]. The prevalence of ASD in TSC varies among studies, but it is estimated to range from $36 \%$ to $50 \%$ [55]. TSC is caused by mutations in two genes: TSC1 (hamartin gene, 9q34) and TSC2 (tuberin gene, 16p13.3) that act as tumor suppressors inhibiting the mammalian target of rapamycin (mTOR) [56]. These events lead to constitutive activation of mTOR complex 1 cascade and the uncontrolled proliferation of cells. In 
neurons, dysfunction of this pathway results in abnormal development of fundamental processes that have been proposed to contribute to the behavioral deficits seen in ASD [55]. Human iPSCs-derived from TSC patients exhibited a delay in their ability to differentiate into neurons that is probably related to a dysregulated PI3K/AKT signaling [45]. Recently, isogenic NPCs derived from a patient carrying a nonsense TSC1 mutation revealed altered early neurodevelopmental phenotypes displaying enhanced proliferation, aberrant neurite outgrowth and enlarged cell size, consistent with mTORC1 activation [46]. However, rapamycin treatment was effective only in reverting enlarged cell size, whereas it was ineffective in increasing proliferation and neurite outgrowth in iPSCs-derived NPCs. Thus, it could be speculated that early neurodevelopmental phenotypes due to TSC1 loss are not solely related to mTORC1 activation. Moreover, transcriptome analysis showed differentially expressed genes (DEGs) related to ASD phenotype with a genotype-dependent linear response: upregulated/downregulated genes were further increased/decreased in homozygous NPCs, generated by CRISPR/Cas9 (clustered regularly interspaced short palindromic repeats/CRISPR-associated protein 9 nuclease) genome editing technology, compared to the heterozygous state [46].

Similarly, genome-wide RNA sequencing was applied to explore DEGs in iPSCs-NPCs and forebrain neurons derived from PMDS probands and unaffected siblings [47]. PMDS (OMIM \#606232), also called 22q13 deletion syndrome, is a rare disease with different clinical features, such as severe intellectual impairments and ASD. A critical region involved three genes, but $S H A N K 3$ is the strongest candidate for the neurobehavioral symptoms [57]. In fact, SHANK3 encodes a scaffolding protein enriched in the postsynaptic density of glutamatergic synapses and plays a critical role in synaptic function and dendrite formation [58]. In PMDS-iPSCs, the authors found an underexpression of genes involved in Wnt signaling, embryonic development, and protein translation, whereas an overexpression was observed in genes related to pre- and post-synaptic signaling, synaptic plasticity regulation and G-protein-gated potassium channels. Interestingly, these data partially overlapped with iPSC transcriptome findings in other ASDs, converging on altered Wnt signaling and extracellular matrix [47].

In 2011, patient-specific iPSCs-derived NPCs and cortical neurons offered new insights into the pathogenesis of TC (OMIM \#601005), a rare and lethal multi-organ disorder connected with gain-of-function missense mutation in the CACNA1C gene (12p13.33) [59], linking its phenotype to defects in $\mathrm{Ca}^{2+}$ signaling and gene expression-dependent activity [48]. In the same study, the authors reported an abnormal expression of tyrosine hydroxylase $(\mathrm{TH})$ and an increased production of norepinephrine and dopamine in neurons, consistent with the key role of catecholamines in sensory gating and social behavior [48]. A genome-wide weighted co-expression network analysis (WGCNA) on NPCs from TS-iPSCs further confirmed dysregulation of $\mathrm{Ca}^{2+}$ signaling in neural development and function [49].

\section{2. iPSCs-Derived Neurons}

Neurons, generated from NSCs during brain development, are electrically excitable cells that transmit information via specialized connections called synapses [60]. Postmortem human brain analysis, as well as functional and structural imaging studies in ASD, showed an impairment in the formation of neuronal networks and synaptogenesis [61,62]. In addition, cerebral tissues displayed altered neuronal phenotype, consisting of reduced soma size, abnormal neuronal morphology, reduced dendritic arborization, fewer dendritic spines and synapses $[63,64]$. Similar morphological alterations were also found in iPSCs-derived neurons from non-syndromic ASD patient carrying a TRPC6 mutation [38]. The same authors demonstrated that the treatment with insulin-like growth factor 1 (IGF-1) or hyperforin, a TRPC6-specific agonist, is able to rescue the neuronal abnormalities, suggesting a possible target for therapeutic strategies in individuals with alterations in this pathway. Interestingly, it has been also shown that MECP2 levels affect TRPC6 expression, hypothesizing common pathways among ASD [38]. Additional iPSCsbased studies in idiopathic ASD reported an imbalance between excitatory and inhibitory 
synapses, leading to deficits in social interaction and behaviors as widely described in autistic individuals [65-68]. An overproduction of GABAergic inhibitory neurons has been observed in iPSCs-derived neurons from patients carrying FOXG1 mutations [69]. In ASD individuals with macrocephaly, other authors reported a reduced synaptogenesis, abnormal neurogenesis and a significant decrease in both inhibitory and excitatory neurotransmitters, leading to functional defects in neuronal networks which were rescued by IGF-1 treatment [45]. A reduced activity of neurons was further observed in a cohort of non-syndromic ASD patients, showing a significant decrease in excitatory neurotransmitter release, synaptic events and, consequently, spontaneous spike rate [31]. In iPSCs-derived neurons from non-syndromic individuals carrying SHANK2 mutations, other authors recently showed a hyperconnectivity as demonstrated by an increase in dendrite length and complexity, synapse number and frequency of spontaneous excitatory post-synaptic currents. Moreover, they also reported altered transcriptional level of genes involved in plasticity, synapse and neuronal morphogenesis [70].

Human iPSCs-derived neurons have been largely used to study a wide range of syndromic ASD forms. Concerning RTT, several groups generated iPSC lines from patients and successfully differentiated them into NPCs and functional neurons. Similarly to results reported for NPCs, iPSCs-derived neurons exhibited increased susceptibility for LINE-1 retrotransposition, probably caused by MECP2 mutations [40]. Marchetto and collaborators [39] showed smaller soma size, reduced dendritic spine densities and fewer synapses in RTT iPSCs-derived neurons in comparison with the isogenic wild-type ones. Moreover, they observed alterations in $\mathrm{Ca}^{2+}$ influx, thus causing electrophysiological defects in the RTT neurons [39]. Conversely, other authors reported that cortical neurons, derived from iPSC lines with $M E C P 2$ duplicated gene, display increased synaptogenesis and dendritic complexity with altered neuronal network synchronization recorded by multi-electrode array (MEA) electrophysiology technique [41]. The functional phenotype was further rescued by the treatment with one histone deacetylase inhibitor, named NCH-51 [51]. RNA-seq profiling on differentiated iPSCs-neurons from RTT patients harboring different MECP2 mutations revealed a prominent enrichment in GABA pathway genes, including GABA receptors and other GABA circuits [71]. Intriguingly, MECP2-mutated neurons showed an impairment of the microtubule network along with a significant decrease of acetylated $\alpha$-tubulin which was reverted by treatment with selective inhibitors of histone deacetylase 6 (HDAC6), the main cytoplasmic deacetylase in which the main substrate is acetylated $\alpha$-tubulin [71]. In regard to CDKL5 deficiency disorder (CDD), an atypical form of RTT, a study successfully generated clones of CDKL5-mutated iPSCs to model disease pathogenesis in vitro [72]. CDD is an X-linked neurological disease caused by pathogenic mutations in the gene for cyclin-dependent kinase-like 5 (CDKL5), a serine-threonine kinase highly expressed in the brain [73]. This rare disease was considered as an atypical variant of RTT; however, it has since been recognized as a distinct disorder with common clinical features, such as early-life seizures, autistic behaviors, and intellectual disability [74]. Interestingly, CDKL5-mutated iPSCs from females maintained X-chromosome inactivation, allowing the use of clones expressing the wild-type allele as ideal experimental controls, genetically identical to those derived from the same patient [72]. In iPSC-derived neurons from patients carrying CDKL5 mutations, a following study detected a loss of synaptic contacts, as well as an increased number of aberrant dendritic spines, demonstrating an interesting role for CDKL5 in spine development and synapse morphogenesis [75].

The majority of studies performed in iPSCs-derived neurons from FXS patients revealed an impairment of neuronal differentiation and maturation as a result of epigenetic differences on FMR1 gene expression [76-80]. Moreover, neurons exhibited a number of additional phenotypic abnormalities, including an altered electrophysiological network activity, neurite outgrowth and branching defects [80,81]. Perturbations in synaptic transmission, cell proliferation and ion transmembrane transporter activity pathways were also reported [80]. Importantly, other authors demonstrated dysregulated $\mathrm{Ca}^{2+}$ signals in 
iPSCs-derived neurons, strengthening the key role of intracellular $\mathrm{Ca}^{2+}$ in neurite growth and synaptic connections [82].

In TSC, iPSCs-derived neurons presented with an enlarged soma, decreased neurite length, complex neurite branching and abnormal connections among cells, as compared to those from unaffected individuals [83]. These abnormalities may be related to hyperactivity of mTOR. Similarly, Zucco et al. generated iPSC-derived NPCs and neurons from two TSC patients reporting a dysregulation of PI3K/AKT/mTORC1 pathway [45]. In mono-cultures of iPSCs-derived cortical neurons, MEA analysis showed an increase in basal dendritic branching and spontaneous $\mathrm{Ca}^{2+}$ event frequency [84], consistent with the network hyperactivity previously observed in the TSC mouse model [85]. It should be noted that these aforementioned studies were performed in iPSCs-derived neurons from TSC patients with heterozygous mutations. In a recent study examining iPSCs-derived neurons carrying either single or biallelic mutations in TSC2, the authors reported that the loss of one or both alleles of TSC2 results in mTORC1 hyperactivation and specific neuronal abnormalities which were partially rescued by pharmacological treatment with mTOR regulator rapamycin [86]. However, only neurons harboring biallelic mutations displayed hyperactivity and upregulation of cell adhesion genes observed in cortical tubers. Collectively, these data suggest that the loss of one allele of TSC2 is sufficient to induce morphological and physiological changes in human neurons, but only with TSC2 biallelic mutations, a gene expression dysregulation could be detected [86].

In PMDS, neurons derived from iPSCs displayed an impairment in excitatory synaptic transmission, depending on both a failure to generate the correct number of excitatory synapses and a decrease in the expression of glutamate receptors [87]. Interestingly, these defects were rescued by restoring SHANK3 expression or treating neurons with IGF-1, thus suggesting a key role of SHANK3 in synapse formation [87]. Moreover, PMDS iPSCs-derived neurons from fibroblasts of 2 children with ASD harboring independent de novo SHANK3 mutations also provided a novel platform for screening active compounds able to reverse SHANK3 haploinsufficiency by increasing SHANK3 protein levels and its recruitment to the glutamatergic synapses [88]. The presence of synaptic abnormalities in ASD patients carrying SHANK3 mutations was further confirmed by a recent study in which iPSCs-derived pyramidal neurons exhibited a significant decrease in dendritic spine densities, as well as in whole spine and spine head volumes [89]. Yi and colleagues studied engineered iPSCs harboring heterozygous and homozygous SHANK3 deletions reporting significant decreases neurite outgrowth, hyperexcitability, increased input resistance and disrupt excitatory synaptic transmission and demonstrated that these excitability deficits were at least in part due to altered surface expression of hyperpolarization-activated cyclic nucleotide-gated (HCN) channels [90].

As already observed in iPSCs-derived NPCs, also neurons from TS patients showed defects in $\mathrm{Ca}^{2+}$ signaling, neuronal differentiation and aberrant expression of $\mathrm{TH}$ that was be reversed by treatment with roscovitine, a cyclin dependent kinase inhibitor [48]. Some authors suggested that a neuronal impairment of $\mathrm{Ca}^{2+}$ signaling may be caused by the increased intracellular $\mathrm{Ca}^{2+}$ influx in rodents and human iPSCs-derived neurons after membrane depolarization. Moreover, they showed that these cells exhibit the activitydependent dendritic retraction [91]. A recent report suggested how aberrant $\mathrm{Ca}_{\mathrm{V}} 1.2$ splicing affects differentiation of the developing cortex during TS pathogenesis [92].

In the first study using iPSCs-based technology for modeling Angelman syndrome (AS, OMIM \#105830) and Prader-Willy Syndrome (PWS, OMIM \#176270), no phenotypic differences were observed in neurons [93]. One of the major genes implicated in ASD is $U B E 3 A$ (ubiquitin protein ligase E3A), gene involved in the AS. This disorder is typically caused by a maternal deletion within chromosome 15q11-q13, containing the gene (70 to $75 \%$ of cases). Other cases can be ascribed to paternal uniparental disomy ( $2 \%$ to $3 \%$ ), imprinting center defect ( $3 \%$ to $5 \%$ ), or single point mutation in the maternal UBE3A allele (5 to 10\%) [94]. Proper gene dosage of $U B E 3 A$ is crucial to normal brain development, as evidenced by the neurodevelopmental disorders associated with this syndrome [95]. 
Importantly, the authors found that $U B E 3 A$ imprinting is established during neuronal differentiation of AS iPSCs through an up-regulated expression of paternal UBE3A antisense transcript (UBE3A-ATS) concomitant with a repression of paternal UBE3A [93]. A subsequent study revealed that the silencing of paternal UBE3A expression by SNHG14 (also named as UBE3A-ATS) induction is a late event during neuronal differentiation [96]. Moreover, it has been shown that iPSCs-derived neurons from AS individuals harboring a large deletion of 15q11-q13 display impaired maturation of resting membrane potential and action potential firing, a reduction in excitatory synaptic activity and a deficit in activity-dependent synaptic plasticity [97].

\section{3. iPSCs-Derived Astrocytes}

Astrocytes, a sub-type of glia, are the most abundant cells in the mammalian CNS and are involved in homeostasis and defense mechanisms. They also play an active role in neurogenesis, synaptogenesis, neuronal support, neurotransmitter recycling, and neuronal network formation [98]. Although the majority of current applications of iPSCs-based technologies in ASD patients have been focused on neurons, glial cells have been shown to play important role in the disorder. Indeed, post-mortem human brain from children with ASD exhibited abnormal glial cell numbers and function [99], as well as an altered density of excitatory synapses, probably caused by impaired synaptic pruning, the natural process by which extra neurons and synaptic connections are removed in order to increase the neuronal network efficiency [100].

In the case of non-syndromic ASD, only one study has been reported so far focused on the interplay between neurons and astrocytes [31]. Co-culture experiments revealed that astrocytes derived from ASD-iPSCs interfere with proper neuronal development. On the contrary, an improvement in the morphology and synaptogenesis of ASD neurons has been demonstrated by combining them with from control iPSCs-derived astrocytes. The same authors reported a high secretion of the pro-inflammatory cytokine interleukin-6 (IL-6) from astrocytes in ASD individuals probably linked to neural defects and showed an increased synaptogenesis by inhibiting IL-6 [31]. Interestingly, reactive astrocytes have been identified to be the main source of cytokines in post-mortem brain tissue of ASD patients [101] and IL-6 was already reported to be increased in plasma [102,103], cerebrospinal fluid [101] and peripheral blood cells of autistic individuals [104].

Astrocytes derived from iPSCs have been also used to study syndromic ASD, such as RTT. Williams and collaborators specifically focused on the glial effects in RTT neurons by differentiating iPSCs in astroglial progenitors and astrocytes [105]. In co-cultures systems, RTT astrocytes affected the phenotype of hippocampal neurons, causing reduced size of soma and number of terminal ends, as well as shorter neurite length, suggesting that the secretion factors from the astrocytes lead to the aberrant neuronal phenotypes. These morphologic abnormalities were partially rescued when neurons were treated with IGF-1 and GPE (a peptide containing the first 3 amino acids of IGF-1), indicating IGF-1 as a potential cellular target for RTT treatment and highlighting potential avenues for drug development [105]. The critical glial contribution to RTT pathology was further confirmed by another study showing a perturbed astrocyte differentiation in iPSC lines that in turn contributed to the functional immaturity of neurons [106].

\section{4. iPSCs-Derived Oligodendrocytes}

Oligodendrocytes are the myelinating glia of the CNS and originate from oligodendrocyte progenitor cells (OPCs), that hold the capacity to proliferate and migrate. They produce myelin sheath, a greatly extended and modified plasma membrane wrapped around the axons, enabling fast saltatory nerve conduction, axon integrity, and thus contributing to the optimal information processing in complex neural networks [107]. As the demyelination is a hallmark of several diseases, oligodendrocytes have become a great cell source for modeling demyelinating disorders [108]. However, increasing studies suggested a possible role of oligodendrocytes also in the ASD pathogenesis [109]. In the left frontal 
cortex of autistic patients, a decreased concentration of $\mathrm{N}$-acetyl aspartate (NAA), an amino acid involved in the myelination support, was found $[110,111]$. Moreover, it has been shown that OPCs isolated from the cortex of TS mice exhibit a more complex morphology and higher protein levels of myelin [112].

Regarding iPSCs-derived oligodendrocytes, only one study has been performed in autistic patients. In the attempt to investigate neuro-glia interactions in TSC phenotypes, the authors found a neuronal hypertrophy and increased axonal density in co-cultures with oligodendrocytes. Moreover, decreased maturation but not cellular proliferation was shown in TSC-oligodendrocytes. Interestingly, pharmacological treatment with rapamycin, mTOR regulator, repressed these defects [84]. Hence, developing models for TSC disease and drug discovery based on the complex interaction between neuronal and glial cells may present a promising tool.

\subsection{Current Challenges for the Applicability of iPSCs in ASD Modeling}

Despite the potential benefits of iPSCs in ASD modeling, there are many challenges that need to be addressed for their applications in clinical setting and pharmacology. The selection of donor cell type (dermal fibroblasts, blood cells or renal tubular cells collected from urine) for the reprogramming process represent the first critical step for the iPSCs generation [4]. It has been shown that skin biopsy-derived dermal fibroblasts and blood cells might carry genetic mutations and chromosomal abnormalities due to exposure to high cell turnover rates and ultra-violet radiation [113]. Depending on the donor cell types, iPSCs can retain some degree of residual epigenetic memory due to an incomplete resetting of the non-CpG methylation patterns during reprogramming processes, thus affecting the differentiation potential [114]. The second step in the generation of iPSCs is the choice of the suitable method for cellular delivery of the reprogramming factors and strategy. The use of retroviruses and lentiviruses can produce an insertional activation of oncogenes and/or inactivation of tumor suppressor genes, leading to a constitutive expression of the reprogramming factors and altering the characteristics and the differentiation potential of iPSCs.

One of the major limitations to the use of iPSCs is the restricted amount of patientderived cell lines that limits the possibility of quantitative analyses [115]. Another issue arising from iPSCs-based modeling in ASD is represented by the selection of a proper control. Indeed, in the majority of studies, unaffected subjects or family members are used as controls, but this can be questionable since each individual has a unique genetic background that could potentially affect the identification of disease-relevant phenotypes.

Like all cultured cells, iPSCs show natural genetic heterogeneity even in cell lines derived from the same individual. Therefore, such diversity can create difficulties at any step of reprogramming somatic cells to iPSCs and may also impair their differentiation ability into desired cell populations [116].

\section{Brain Organoid Models of ASDs}

Three-dimensional self-organized neural cultures rely on the ability of iPSCs or, more in general, stem cell to self-organize in 3D structures, frequently named mini-brain, providing also required self-patterning factors for morphogenesis and differentiation [117]. These organoids are able to sum up sequential neurogenesis, migration, gliogenesis, and synaptogenesis of cortical development that cannot be studied in 2D cell cultures [118]. Being able to be maintained in vitro for up to two years [119], they could reach later stages of neurodevelopment compared to those that can be studied with 2D cultures and, thus, produce later-born neural cells, including astrocytes and oligodendrocytes [119,120].

One of the first study on brain organoid deriving from cells of patients affected by idiopathic ASD and characterized by macrocephaly [69] reported abnormalities in cellcycle and synaptic growth. In particular, they noted an increment in the expression of the transcription factor FOXG1 that correlated with an increased production of inhibitory neurons. The study highlights the role of this gene and suggests it as a potential therapeutic 
target [69]. More recently, Schafer and colleagues [121] performed a large study, based on a selected cohort of macrocephalic ASD patients, in which they combined direct iPSCsto neuron conversion, transcriptomic analysis and cerebral organoids generation. This strategy made it possible to clarify that ASD-related neurodevelopmental abnormalities are triggered by a specific temporal sequence of gene networks dysregulation. The study showed different results in forebrain organoids than in iPSC-derived neurons. In particular, ASD alterations were well recapitulated in organoids, while the direct conversion of iPSCs to mature neurons abolished ASD-associated phenotypes [121]. Owing to the fact that $C H D 8$, a gene encoding for a chromatin-remodeling factor, is mutated in a subgroup of patients with ASD and schizophrenia (SZ), some authors performed an RNA-seq analysis of cerebral organoids derived from iPSCs that are heterozygous for a CHD8 knockout allele, and from isogenic controls [122]. The study showed that CHD8 regulates the expression of other genes implicated in ASD and SZ, in particular TCF4 and AUTS2, and a large overlap was observed for DEGs found by Mariani et al. [69], especially for genes involved in GABAergic interneuron development. Pathway analysis of DEGs revealed an enrichment of genes involved in regulating Wnt/ $\beta$-catenin signaling, a druggable pathway [122].

Organoids were used also to study RTT pathogenesis. In particular, Mellios and colleagues [123] analyzed alterations in different neuronal processes, such as neurogenesis, differentiation, and migration, in MECP2-deficient and patient-derived cerebral organoids, while, more recently, Xiang et al. [124] performed a transcriptome analyses revealing a cell-type-specific impairment in specific regions of brain organoids carrying $M E C P 2$ mutations.

In a recent study performed by combining CRISPR/Cas9 genome editing and brain organoids, Blair et al. [125], investigating the "two hit hypothesis" model of cortical tuber formation, demonstrated that homozygous, but not heterozygous, loss of either TSC1 or TSC2 impairs the developmental suppression of mTORC1 signaling. Moreover, they demonstrated that the development of TSC phenotype in organoid could be prevented by treating them with rapamycin $[125,126]$.

Brain organoids were also successfully obtained from patient affected by TS in a study that represents the first example of fused organoid approach for the in vitro study neuronal circuits involving different brain regions [127]. In particular, authors studied the migration pattern of inhibitory neurons during brain development using live imaging of TS-forebrain assembloids (fused cerebral organoids resembling the dorsal and ventral forebrain regions). They demonstrated that TS interneurons display a cell-autonomous defect consisting in overall delayed migration from the ventral to the dorsal forebrain [127]. The functional phenotype was rescued by treatment with nimodipine, a drug inhibiting the activity of L-type calcium channel.

Very recently, brain organoids were studied to go deep inside into the pathological mechanisms underlying AS [128]. The study demonstrated that UBE3A suppresses neuronal hyperexcitability via ubiquitin-mediated degradation of calcium and voltagedependent big potassium (BK) channels. Thus, the use of a BK channels antagonist could normalize neuronal excitability ameliorating also seizure susceptibility [128].

\section{Current Challenges for the Applicability of Brain Organoids in ASD Modeling}

Considering all the above reported studies (summarized in Table 2), besides the high cost of culturing organoids, there are still some challenges facing their use for studying ASD. As compared to 2D monolayer, 3D cultures can be more heterogeneous, displaying high variability in both the structure and the composition of organoids between cell lines, between individual experiments using the same cell lines and even between single organoids derived from the same cell line in the same experiment [129]. The high variability across batches is often the result of the stochastic nature of spontaneous neural in brain organoids, thus making quantitative studies challenging. 
Table 2. Summary of main iPSCs-based studies as a model of ASD.

\begin{tabular}{|c|c|c|c|c|c|}
\hline Disease & $\begin{array}{l}\text { Genetic Mutations } \\
\text { in Samples }(n)\end{array}$ & $\begin{array}{l}\text { iPSCs-Based } \\
\text { Models }\end{array}$ & Relevant Findings & Effective Drugs & Reference \\
\hline \multirow[t]{9}{*}{$\begin{array}{c}\text { Non-syndromic } \\
\text { ASD }\end{array}$} & $\begin{array}{c}\text { different } \\
\text { no ASD-related } \\
\text { variants }(3)\end{array}$ & $\begin{array}{l}\text { neurons and } \\
\text { astrocytes }\end{array}$ & $\begin{array}{l}\text { decreased synapses and } \\
\text { release of excitatory } \\
\text { neurotransmitters, glial } \\
\text { dysfunction, and high } \\
\text { levels of IL-6 }\end{array}$ & anti-IL-6 & [31] \\
\hline & $\begin{array}{c}\text { different } \\
\text { no ASD-related } \\
\text { variants }(8)\end{array}$ & $\begin{array}{l}\text { NPCs and } \\
\text { neurons }\end{array}$ & $\begin{array}{l}\text { increased proliferation } \\
\text { in NPCs, abnormal } \\
\text { neurogenesis, reduced } \\
\text { synaptogenesis, and } \\
\text { decreased release of } \\
\text { inhibitory/excitatory } \\
\text { neurotransmitters }\end{array}$ & IGF-1 & [35] \\
\hline & $\begin{array}{c}\text { different } \\
\text { no ASD-related } \\
\text { variants }(3)\end{array}$ & NPCs & $\begin{array}{l}\text { hyperproliferation } \\
\text { of NPCs }\end{array}$ & & [36] \\
\hline & $\begin{array}{l}\text { rare compound } \\
\text { heterozygous } \\
\text { missense variants in } \\
\text { RELN (1) }\end{array}$ & NPCs & $\begin{array}{l}\text { impaired crosstalk } \\
\text { between mTORC1 and } \\
\text { Reelin-DAB1 pathways }\end{array}$ & rapamycin & [37] \\
\hline & $\begin{array}{l}\text { de novo balanced } \\
\text { translocation in } \\
\text { TRPC6 (1) }\end{array}$ & $\begin{array}{l}\text { NPCs and } \\
\text { neurons }\end{array}$ & $\begin{array}{l}\text { abnormal neuronal } \\
\text { development and } \\
\text { morphology, fewer } \\
\text { dendritic spines and } \\
\text { synapses }\end{array}$ & $\begin{array}{l}\text { IGF-1 and } \\
\text { hyperforin }\end{array}$ & [38] \\
\hline & $\begin{array}{l}\text { loss-of-function } \\
\text { mutations in FOXG1 (4) }\end{array}$ & $\begin{array}{l}\text { neurons } \\
\text { and brain } \\
\text { organoids }\end{array}$ & $\begin{array}{c}\text { overproduction of } \\
\text { GABAergic neurons and } \\
\text { GABA } \\
\text { neurotransmitter }\end{array}$ & & [69] \\
\hline & $\begin{array}{c}\text { heterozygous } \\
\text { loss-of-function } \\
\text { mutations in SHANK2 (2) }\end{array}$ & neurons & $\begin{array}{l}\text { increased dendrite } \\
\text { length and complexity, } \\
\text { synapse number, and } \\
\text { frequency of } \\
\text { spontaneous excitatory } \\
\text { post-synaptic currents }\end{array}$ & $\begin{array}{c}\text { agonist of mGluRs } \\
\text { DHPG }\end{array}$ & [70] \\
\hline & $\begin{array}{c}\text { different } \\
\text { no ASD-related } \\
\text { variants }(8)\end{array}$ & $\begin{array}{c}\text { brain } \\
\text { organoids }\end{array}$ & $\begin{array}{c}\text { neurodevelopmental } \\
\text { abnormalities triggered } \\
\text { by temporal } \\
\text { dysregulation of } \\
\text { specific gene networks }\end{array}$ & & [121] \\
\hline & $\begin{array}{l}\text { heterozygous } \\
\text { knockout of } \\
\text { CHD8 (1) }\end{array}$ & $\begin{array}{l}\text { brain } \\
\text { organoids }\end{array}$ & $\begin{array}{l}\text { enrichment of genes } \\
\text { involved in GABAergic } \\
\text { interneuron } \\
\text { development and } \\
\text { Wnt/ } \beta \text {-catenin } \\
\text { signaling }\end{array}$ & & [122] \\
\hline
\end{tabular}


Table 2. Cont

\begin{tabular}{|c|c|c|c|c|c|}
\hline Disease & $\begin{array}{l}\text { Genetic Mutations } \\
\text { in Samples }(n)\end{array}$ & $\begin{array}{l}\text { iPSCs-Based } \\
\text { Models }\end{array}$ & Relevant Findings & Effective Drugs & Reference \\
\hline \multirow[t]{9}{*}{ RTT } & $\begin{array}{l}\text { missense, frameshift and } \\
\text { nonsense } \\
\text { mutations in } M E C P 2(4)\end{array}$ & $\begin{array}{l}\text { NPCs and } \\
\text { neurons }\end{array}$ & $\begin{array}{c}\text { reduced soma size, } \\
\text { dendritic spine } \\
\text { densities and synapses, } \\
\text { altered } \mathrm{Ca}^{2+} \\
\text { signaling, and } \\
\text { electrophysiological } \\
\text { defects }\end{array}$ & $\begin{array}{l}\text { IGF-1 and } \\
\text { gentamicin }\end{array}$ & [39] \\
\hline & $\begin{array}{l}\text { frameshift mutation in } \\
\qquad M E C P 2(1)\end{array}$ & $\begin{array}{l}\text { NPCs and } \\
\text { neurons }\end{array}$ & $\begin{array}{l}\text { increased frequency } \\
\text { of de novo } \\
\text { LINE-1 } \\
\text { retrotransposition }\end{array}$ & & [40] \\
\hline & $\begin{array}{l}\text { different } \\
\text { duplications in } \\
M E C P 2(3)\end{array}$ & $\begin{array}{l}\text { NPCs and } \\
\text { neurons }\end{array}$ & $\begin{array}{l}\text { altered expression of } \\
\text { neuronal progenitor } \\
\text { genes, increased } \\
\text { synaptogenesis and } \\
\text { dendritic complexity } \\
\text { with altered } \\
\text { network } \\
\text { synchronization }\end{array}$ & $\begin{array}{l}\text { histone deacetylase } \\
\text { inhibitor } \\
\text { NCH-51 }\end{array}$ & [41] \\
\hline & $\begin{array}{c}\text { large } \\
\text { deletion in } \\
M E C P 2(1)\end{array}$ & $\begin{array}{l}\text { NPCs and } \\
\text { cortical neurons }\end{array}$ & $\begin{array}{l}\text { repressed translation } \\
\text { and } \\
\text { decreased } \\
\text { ribosome engagement of } \\
\text { NEDD4-family } \\
\text { ubiquitin ligases }\end{array}$ & & [42] \\
\hline & $\begin{array}{l}\text { missense mutations in } \\
M E C P 2(2)\end{array}$ & neurons & $\begin{array}{l}\text { impaired microtubule } \\
\text { network and decreased } \\
\text { acetylated } \alpha \text {-tubulin }\end{array}$ & $\begin{array}{l}\text { selective } \\
\text { inhibitors of } \\
\text { HDAC6 }\end{array}$ & [71] \\
\hline & $\begin{array}{c}\text { missense and } \\
\text { nonsense mutations in } \\
M E C P 2(3)\end{array}$ & $\begin{array}{l}\text { neurons and } \\
\text { astrocytes }\end{array}$ & $\begin{array}{c}\text { neuronal } \\
\text { morphological } \\
\text { abnormalities mediated } \\
\text { by mutant astrocytes }\end{array}$ & IGF-1 and GPE & [105] \\
\hline & $\begin{array}{c}\text { missense and } \\
\text { nonsense mutations in } \\
M E C P 2(2)\end{array}$ & astrocytes & $\begin{array}{l}\text { perturbed astrocyte } \\
\text { differentiation }\end{array}$ & & [106] \\
\hline & $\begin{array}{l}\text { missense and frameshift } \\
\text { mutations in } M E C P 2(2)\end{array}$ & $\begin{array}{c}\text { brain } \\
\text { organoids }\end{array}$ & $\begin{array}{l}\text { impaired neurogenesis, } \\
\text { neuronal differentiation } \\
\text { and migration }\end{array}$ & & [123] \\
\hline & $\begin{array}{c}\text { missense and } \\
\text { nonsense mutations in } \\
M E C P 2(3)\end{array}$ & $\begin{array}{c}\text { brain } \\
\text { organoids }\end{array}$ & $\begin{array}{l}\text { cell-type-specific } \\
\text { impairments }\end{array}$ & $\begin{array}{c}\text { BET } \\
\text { inhibitor JQ1 }\end{array}$ & [124] \\
\hline \multirow[t]{2}{*}{ CDKL5 disorder } & $\begin{array}{c}\text { missense and } \\
\text { nonsense mutations in } \\
\text { CDKL5 (2) }\end{array}$ & neurons & $\begin{array}{l}\text { decreased density of } \\
\text { dendritic spines and } \\
\text { reduced number of } \\
\text { excitatory synapse }\end{array}$ & & [72] \\
\hline & $\begin{array}{l}\text { translocation } \mathrm{t}(7 ; \mathrm{X}) \\
\text { inactivating } \\
\text { CDKL5 (1) }\end{array}$ & neurons & $\begin{array}{c}\text { decreased density of } \\
\text { dendritic spines and loss } \\
\text { of } \\
\text { synaptic contacts }\end{array}$ & & [75] \\
\hline
\end{tabular}


Table 2. Cont

\begin{tabular}{|c|c|c|c|c|c|}
\hline Disease & $\begin{array}{l}\text { Genetic Mutations } \\
\text { in Samples }(n)\end{array}$ & $\begin{array}{l}\text { iPSCs-Based } \\
\text { Models }\end{array}$ & Relevant Findings & Effective Drugs & Reference \\
\hline \multirow[t]{6}{*}{ FXS } & $\begin{array}{l}>200 \text { CGG repeats in } \\
\text { 5'UTR FMR1 (3) }\end{array}$ & NPCs & $\begin{array}{l}\text { abnormal expression of } \\
\text { key NPC genes (SOX1, } \\
\text { NOTCH1, PAX6) }\end{array}$ & & [43] \\
\hline & $\begin{array}{l}>200 \text { CGG repeats in } \\
\text { 5'UTR FMR1 (4) }\end{array}$ & NPCs & $\begin{array}{c}\text { impaired } \mathrm{Ca}^{2+} \text { signaling } \\
\text { affecting neuronal } \\
\text { differentiation }\end{array}$ & & {$[44]$} \\
\hline & $\begin{array}{l}>700 \text { CGG repeats in } \\
\text { 5'UTR FMR1 (3) }\end{array}$ & neurons & $\begin{array}{l}\text { impaired neuronal } \\
\text { differentiation and } \\
\text { maturation }\end{array}$ & & [76] \\
\hline & FMR1 knockout (2) & neurons & $\begin{array}{c}\text { abnormal synaptic } \\
\text { transmission, neuronal } \\
\text { differentiation, and cell } \\
\text { proliferation }\end{array}$ & & [80] \\
\hline & $\begin{array}{l}>700 \text { CGG repeats in } \\
\text { 5'UTR FMR1 (3) }\end{array}$ & neurons & $\begin{array}{l}\text { altered neurite } \\
\text { outgrowth and } \\
\text { branching defects }\end{array}$ & & [81] \\
\hline & $\begin{array}{c}94 \text { CGG repeats in } 5^{\prime} \mathrm{UTR} \\
\text { FMR1 (1) }\end{array}$ & neurons & $\begin{array}{l}\text { dysregulated } \mathrm{Ca}^{2+} \\
\text { signals, reduced } \\
\text { synaptic protein } \\
\text { expression, and } \\
\text { shorter neurites }\end{array}$ & & [82] \\
\hline \multirow[t]{6}{*}{ TSC } & $\begin{array}{c}\text { de novo mutations in } \\
\text { TSC2 (2) }\end{array}$ & $\begin{array}{l}\text { NPCs and } \\
\text { neurons }\end{array}$ & $\begin{array}{l}\text { delayed neuronal } \\
\text { differentiation }\end{array}$ & & [45] \\
\hline & $\begin{array}{l}\text { nonsense mutation } \\
\text { in TSC1 (1) }\end{array}$ & NPCs & $\begin{array}{l}\text { enhanced proliferation, } \\
\text { aberrant neurite } \\
\text { outgrowth, and } \\
\text { enlarged cell size }\end{array}$ & rapamycin & [46] \\
\hline & $\begin{array}{c}\text { splicing mutation in TSC1 } \\
\text { (1) }\end{array}$ & neurons & $\begin{array}{l}\text { enlarged soma, } \\
\text { decreased neurite length, } \\
\text { and abnormal } \\
\text { connections }\end{array}$ & & [83] \\
\hline & $\begin{array}{l}\text { de novo mutation } \\
\text { in TSC1 and frameshift } \\
\text { mutation in TSC2 (2) }\end{array}$ & $\begin{array}{l}\text { co-cultures of } \\
\text { cortical } \\
\text { neurons and } \\
\text { oligodendro- } \\
\text { cytes }\end{array}$ & $\begin{array}{c}\text { cellular hypertrophy } \\
\text { and } \\
\text { increased } \\
\text { axonal density }\end{array}$ & rapamycin & [84] \\
\hline & $\begin{array}{l}\text { single or biallelic } \\
\text { mutations in } \\
\text { TSC2 (2) }\end{array}$ & neurons & morphological changes & rapamycin & [86] \\
\hline & $\begin{array}{c}\text { loss-of-function } \\
\text { mutations in TSC1 and } \\
\text { TSC2 (2) }\end{array}$ & brain organoids & $\begin{array}{c}\text { impaired } \\
\text { developmental } \\
\text { suppression of mTORC1 } \\
\text { signaling } \\
\text { by loss of either } \\
\text { TSC1 or TSC2 }\end{array}$ & rapamycin & [125] \\
\hline \multirow[t]{2}{*}{ PMDS } & $\begin{array}{l}\text { small/large 22q13.3 } \\
\text { deletions and frameshift } \\
\text { mutation in SHANK3 (7) }\end{array}$ & NPCs & $\begin{array}{l}\text { disrupted neurogenesis } \\
\text { leading to altered } \\
\text { excitatory/inhibitory } \\
\text { balance }\end{array}$ & & [47] \\
\hline & $\begin{array}{c}22 \mathrm{q} 13 \\
\text { deletion (2) }\end{array}$ & neurons & $\begin{array}{l}\text { impaired excitatory } \\
\text { synaptic transmission }\end{array}$ & IGF-1 & [87] \\
\hline
\end{tabular}


Table 2. Cont.

\begin{tabular}{|c|c|c|c|c|c|}
\hline Disease & $\begin{array}{l}\text { Genetic Mutations } \\
\text { in Samples }(n)\end{array}$ & $\begin{array}{l}\text { iPSCs-Based } \\
\text { Models }\end{array}$ & Relevant Findings & Effective Drugs & Reference \\
\hline & $\begin{array}{l}\text { de novo truncating and } \\
\text { frameshift } \\
\text { mutations in SHANK3 (2) }\end{array}$ & neurons & $\begin{array}{l}\text { impaired excitatory } \\
\text { synaptic transmission }\end{array}$ & $\begin{array}{l}\text { lithium } \\
\text { and valproic acid }\end{array}$ & [88] \\
\hline & $\begin{array}{l}\text { de novo truncating } \\
\text { mutations in SHANK3 (4) }\end{array}$ & $\begin{array}{l}\text { pyramidal } \\
\text { neurons }\end{array}$ & $\begin{array}{l}\text { decreased dendritic } \\
\text { spines and altered } \\
\text { spinogenesis }\end{array}$ & & [89] \\
\hline & $\begin{array}{c}\text { heterozygous and } \\
\text { homozygous SHANK3 } \\
\text { deletions ( } 2)\end{array}$ & neurons & $\begin{array}{l}\text { decreased neurite } \\
\text { outgrowth, } \\
\text { hyperexcitability, } \\
\text { increased input } \\
\text { resistance, and } \\
\text { disrupted excitatory } \\
\text { synaptic transmission }\end{array}$ & & [90] \\
\hline \multirow[t]{5}{*}{ TS } & $\begin{array}{c}\text { G406R missense } \\
\text { mutation in CACNA1C (5) }\end{array}$ & $\begin{array}{l}\text { NPCs and } \\
\text { neurons }\end{array}$ & $\begin{array}{c}\text { dysregulated } \mathrm{Ca}^{2+} \\
\text { signaling, impaired } \\
\text { neuronal } \\
\text { differentiation, } \\
\text { increased } \mathrm{TH} \text { and } \\
\text { catecholamine } \\
\text { expression }\end{array}$ & roscovitine & [48] \\
\hline & $\begin{array}{c}\text { G406R missense } \\
\text { mutation in CACNA1C (3) }\end{array}$ & NPCs & $\begin{array}{c}\text { dysregulated } \mathrm{Ca}^{2+} \\
\text { signaling affecting } \\
\text { neuronal development } \\
\text { and function }\end{array}$ & & [49] \\
\hline & $\begin{array}{c}\text { G406R missense } \\
\text { mutation in CACNA1C (2) }\end{array}$ & neurons & $\begin{array}{l}\mathrm{Ca}^{2+} \text {-dependent } \\
\text { dendritic retraction and } \\
\text { altered cellular } \\
\text { structure }\end{array}$ & $\begin{array}{c}\mathrm{C} 3 \\
\text { transferase }\end{array}$ & [91] \\
\hline & $\begin{array}{c}\text { G406R missense } \\
\text { mutation in CACNA1C (3) }\end{array}$ & neurons & $\begin{array}{l}\text { altered differentiation in } \\
\text { the developing } \\
\text { cortex }\end{array}$ & & [92] \\
\hline & $\begin{array}{c}\text { G406R missense } \\
\text { mutation in CACNA1C (3) }\end{array}$ & brain organoids & $\begin{array}{l}\text { delayed migration of } \\
\text { inhibitory neurons }\end{array}$ & nimodipine & [127] \\
\hline \multirow[t]{4}{*}{ AS } & $\begin{array}{c}\text { maternal } 15 q 11-q 13 \\
\text { deletion including } U B E 3 A \\
\text { (2) }\end{array}$ & neurons & $\begin{array}{l}\text { no phenotypic } \\
\text { alterations }\end{array}$ & & [93] \\
\hline & $\begin{array}{c}\text { 3bp deletion in the } \\
\text { maternally inherited } \\
\text { UBE3A (1) }\end{array}$ & neurons & $\begin{array}{c}\text { late paternal } U B E 3 A \\
\text { silencing during } \\
\text { neuronal } \\
\text { differentiation }\end{array}$ & & [96] \\
\hline & $\begin{array}{l}\text { large } 15 q 11-q 13 \\
\text { deletion (3) }\end{array}$ & neurons & $\begin{array}{l}\text { reduced synaptic } \\
\text { activity and plasticity }\end{array}$ & & [97] \\
\hline & $\begin{array}{c}15 \mathrm{q} 11.2-\mathrm{q} 13 \\
\text { microdeletion } \\
\text { including } U B E 3 A(1)\end{array}$ & brain organoids & $\begin{array}{c}\text { neuronal } \\
\text { hyperexcitability }\end{array}$ & $\begin{array}{c}\text { BK } \\
\text { channels } \\
\text { antagonist }\end{array}$ & [128] \\
\hline PWS & $\begin{array}{l}\text { paternal 15q11-13 } \\
\text { deletion (1) }\end{array}$ & neurons & $\begin{array}{l}\text { no phenotypic } \\
\text { alterations }\end{array}$ & & [93] \\
\hline
\end{tabular}

BET, bromodomain and extra-terminal; BK, voltage-dependent big potassium channels; DHPG, 3,5 dihydroxyphenylglycine; GPE, peptide containing the first 3 amino acids of IGF-1; HDAC6, histone deacetylase 6; IGF-1, insulin-like growth factor 1; NPCs, neural progenitor cells; $\mathrm{TH}$, tyrosine hydroxylase. 
A limitation to the use of brain organoids for ASD modeling includes the lack of transport of nutrients and oxygen to cells through the vascularization which can ultimately induce hypoxia and inner necrosis. This also represent an obstacle to the study of bloodbrain-barrier (BBB) interactions that is relevant for drug delivery to the brain. Moreover, the lack of vascularization in the neural tissue affects long-term maturation of cerebral organoids, which is extremely relevant to achieve a high degree of cellular complexity and neuronal maturity, including formation of dendritic spines and spontaneously active neuronal networks.

Although brain organoids contain most of the cerebral cell types, microglia are absent from iPSCs-derived brain organoids because of its embryonic origin distinct from that of neural progenitors [130]. As microglia regulate the synaptic pruning, thus contributing to the formation and maintenance of neural circuits [131], it is, therefore, difficult to model these cellular aspects of ASD.

\section{Use of ASD Models for Drug Discovery and Development}

The use of iPSCs as a tool has helped to unveil not only the etiology of ASD, but also aided the progress of the therapeutic areas. Mouse models have routinely been used to test drug candidates, but those identified to date have shown low efficacy in humans, thus limiting their translational potential $[132,133]$. Moreover, the development of drugs for ASD treatment is still challenging due to the high heterogeneity of the phenotypes, the limited understanding of its pathophysiology, and difficulties in modeling ASD both in vitro and in vivo.

Besides their value for the uncovering of cellular and molecular phenotypes underlying ASD, human iPSCs-based technologies have offered novel possibilities for personalized medicine and for screening drug candidates that can rescue normal phenotype and function. Among them, different iPSCs studies provided evidence that IGF-1 ameliorates some physiological deficits associated with ASD, both in non-syndromic $[35,36]$ and syndromic forms $[39,87,105]$. In particular, this growth factor was able to restore impaired neuronal network [35], synaptic deficits [38,39,87], or neuronal morphological abnormalities [105] in iPSCs-derived neurons. The evidences coming from iPSCs-based studies in RTT and PMDS modeling have led to a stage II clinical trial on IGF-1 for the treatment of idiopathic and syndromic ASD with results expected in 2022 (https: / /ClinicalTrials.gov; protocols numbers: NCT01970345; NCT01894958; NCT01777542; NCT01525901; NCT01253317) [134,135]. Furthermore, gentamicin treatment on RTT iPSCs-derived neurons enhanced MECP2 protein levels and increased glutamatergic synapse, further confirming that patient-specific iPSCs can correct neuronal phenotypes [39]. Given MECP2 function at the epigenetic level, some authors planned to screen a library of 43 compounds with defined activity on epigenetic pathways in order to test the reversibility of the alterations observed in iPSCs-derived neurons harboring MECP2 duplicated gene. Among them, the histone deacetylase inhibitor $\mathrm{NCH}-51$ was validated as a potential clinical candidate [41]. Intriguingly, in another study performed on iPSCs from MECP2-mutated neurons, phenotypic abnormalities were reverted by the treatment with selective inhibitors of HDAC6, the main $\alpha$-tubulin deacetylase [71]. As mentioned above, other promising results were achieved by roscovitine that can reverse altered expression of $\mathrm{TH}$ and increased production of norepinephrine and dopamine displayed in iPSCs-derived neurons from TS individuals carrying a mutation in $C A C N A 1 C$ gene [48]. Additionally, the pharmacological intervention with rapamycin, mTOR regulator, successfully recapitulated the increased neuronal activity and morphological changes in TSC iPSCs-derived neurons, suggesting that these cells can also respond to existing drugs in vitro $[84,86,125]$. In this regard, it should be noted that clinical studies already showed encouraging improvements in TSC patients after treatment with rapamycin [136].

The aforementioned findings are very promising and suggest that disease-specific models based on iPSCs may represent an emerging and scalable platform for developing novel therapeutic agents targeting molecular mechanisms for ASD treatment (Figure 2). 
Since iPSCs are renewable, they can provide unlimited cellular resources for large-scale high-throughput screening (HTS). In this regard, one HTS was performed in iPSCs-derived cortical neurons from ASD individuals harboring SHANK3 mutations to search for compounds that rescue SHANK3-associated phenotypes by increasing its mRNA levels. Among 202 tested compounds, lithium and valproic acid were identified as agents with the best efficacy to correct SHANK3 haploinsufficiency, demonstrating that iPSCs can offer a novel cellular platform for developing specific disease-modifying treatments [88]. However, HTS platforms for drug discovery are still under development and require further standardization, including a homogeneity of cell types and a speeding up of the neuronal maturation by improving the differentiation protocols. Although the current advances in iPSC-based systems hold great promises for drug discovery, these technologies cannot completely replace animal models for preclinical evaluation of drugs.

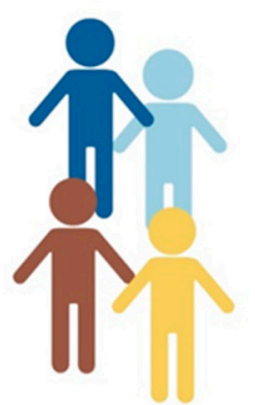

Patients with genetic ASD

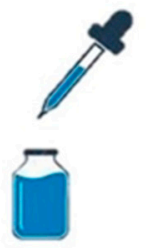

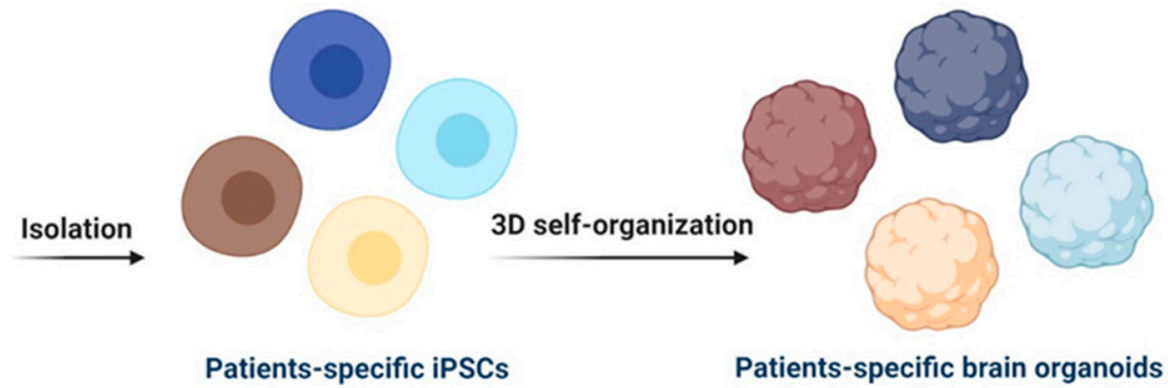
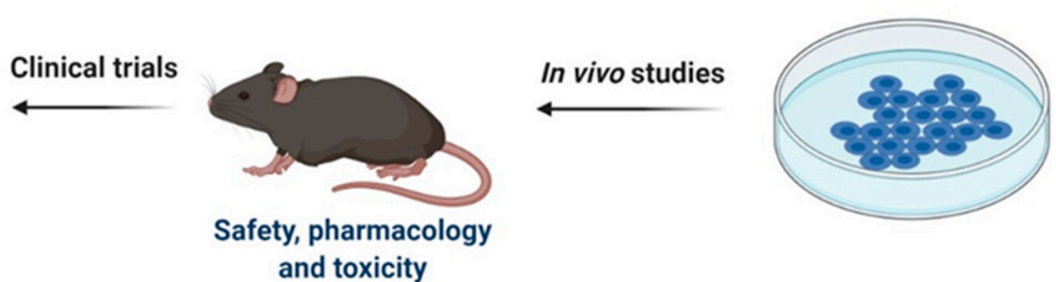
screening

Figure 2. Schematic representation of iPSCs-based models for drug discovery and development in ASD. Specific iPSCs can be isolated from patients with genetic ASD and can be further differentiated into patients-specific iPSCs or 3D selforganized in brain organoids. Potential drug screening can be performed in both 2D cultures of iPSCs-derived cells types of the CNS and in brain organoids. Selected drug candidates can be then firstly tested in in vivo models for safety, pharmacology, and toxicity and then used for clinical trials in humans. This figure was created with BioRender.com (accessed on 11 February 2021).

\section{Conclusions and Future Directions}

ASD is becoming an epidemiologically relevant pediatric disease owing to the increase in the prevalence with time in children [12]. A variety of iPSC-based models have already provided valuable insights into the molecular and cellular mechanisms underpinning several forms of ASD, also offering an unprecedented platform to perform drug screening. However, a number of challenges still remain in using iPSCs for ASD modeling (Table 3). To overcome the limited number of cell lines, one way could consist in the collection of cells derived from both affected and unaffected individuals to be biobanked, thus allowing the large-scale use of iPSCs-based technology. Currently, a biobank has already been created with a collection of about 300 stem cell lines obtained from the tooth pulp of ASD subjects [137] and another with more than 200 fibroblasts, iPSCs, and NSCs, as well as glial cells, generated from ASD individuals and normal unaffected volunteers as controls [138]. 
Table 3. Current limitations of iPSCs and potential solutions/approaches in ASD modeling.

\begin{tabular}{|c|c|}
\hline Limitations of iPSCs & Potential Solutions/Approaches \\
\hline $\begin{array}{l}\text { Limited amount of } \\
\text { patient-derived cell lines }\end{array}$ & Generation of biobanks of cells derived from patients and unaffected individuals \\
\hline Lack of proper ASD control & Use of TALEN and CRISPR/Cas9 genome-editing techniques to create isogenic cell lines \\
\hline Line-to-line variability & $\begin{array}{l}\text { Use of TALEN and CRISPR/Cas9 genome-editing techniques to create isogenic cell lines } \\
\text { More defined differentiation procedures for both 2D and 3D cultures }\end{array}$ \\
\hline $\begin{array}{l}\text { Lack of organoid-to-organoid } \\
\text { reproducibility }\end{array}$ & Use of 3D bioprinting models \\
\hline Lack of vascularization & $\begin{array}{l}\text { In Vivo transplantation in animal models } \\
\text { Use of combined progenitors (neural and mesenchymal stem cells) } \\
\text { Promotion of blood vessel formation by VEGF supplementation in brain organoids }\end{array}$ \\
\hline Limited long-term maturation of brain organoids & $\begin{array}{c}\text { Optimization of growth conditions by spinning bioreactors } \\
\text { In vivo transplantation in animal models }\end{array}$ \\
\hline High cost of culturing organoids & Miniaturized bioreactors with reduced incubator space and decreased volume of media \\
\hline
\end{tabular}

The use of genome editing, such as TALEN (transcription activator-like effector nuclease) and CRISPR/Cas9 techniques, is moving to address the selection of a proper control, offering the possibility to generate isogenic cell lines differing only for the specific targeted mutation $[139,140]$. The use of these technologies can also reduce the problem of line-toline variability by applying more defined differentiation procedures to both $2 \mathrm{D}$ and 3D cultures. Interestingly, 3D bioprinting models have been recently proposed to increase the throughput and reproducibility of organoid generation [141]. This technology can bring together biomaterials, bioactive factors, and cells to build 3D neural tissue, mimicking in vivo neural architecture characteristics and thus allowing the precise control of brain organoid structure [142].

In vivo transplantation of human neural organoids into adult murine brains [143] or the combined use of neural and mesenchymal stem cells [144] should represent valuable solutions for overcoming the lack of transport of nutrients and oxygen. Another approach to incorporate vasculature consists in the supplementation of endothelial vascular growth factor (VEGF) which was shown to successfully promote blood vessel formation in brain organoids [145]. This limitation can also be overcome by the use of engineering devices, such as spinning bioreactors that improve growth conditions, thus allowing the longterm culture of organoids [6]. Miniaturized bioreactors with reduced incubator space and decreased volume of media have also been developed for reducing the high cost of culturing organoids that precludes scalability and compound screening in many laboratories [146].

Despite these current limitations, the combination of iPSCs-based technology with genome editing, organoid engineering or other advances techniques could optimize and refine these iPSCs-derived system models for an extensive clinical application and a better understanding of ASD pathogenesis.

Supplementary Materials: The following are available online at https:/ /www.mdpi.com/1999-492 3/13/2/280/s1, Table S1: Main ASD-associated syndromes.

Author Contributions: C.V., R.C. and D.C. carried out the literature review and wrote the manuscript. C.V. and R.C. conceptualized the manuscript. R.C. provided critical inputs. M.L. performed interpretation of data and edited the manuscript. All authors have read and agreed to the published version of the manuscript.

Funding: This research was funded by European Commission H2020-EU.1.4.1.1. ID-EPTRI (InfradevEuropean Paediatric Translational Research Infrastructure), grant number 777554 to M.L.

Institutional Review Board Statement: Not applicable.

Informed Consent Statement: Not applicable.

Data Availability Statement: Not applicable.

Acknowledgments: All the figures were created with BioRender.com (accessed on 11 February 2021). 
Conflicts of Interest: The authors declare no conflict of interest.

\section{References}

1. Shi, Y.; Inoue, H.; Wu, J.C.; Yamanaka, H.I.S. Induced pluripotent stem cell technology: A decade of progress. Nat. Rev. Drug Discov. 2017, 16, 115-130. [CrossRef]

2. Takahashi, K.; Yamanaka, S. Induction of Pluripotent Stem Cells from Mouse Embryonic and Adult Fibroblast Cultures by Defined Factors. Cell 2006, 126, 663-676. [CrossRef]

3. Nam, K.H.; Yi, S.A.; Jang, H.J.; Han, J.-W.; Lee, J. In Vitro modeling for inherited neurological diseases using induced pluripotent stem cells: From 2D to organoid. Arch. Pharmacal Res. 2020, 43, 877-889. [CrossRef]

4. Takahashi, K.; Tanabe, K.; Ohnuki, M.; Narita, M.; Ichisaka, T.; Tomoda, K.; Yamanaka, S. Induction of Pluripotent Stem Cells from Adult Human Fibroblasts by Defined Factors. Cell 2007, 131, 861-872. [CrossRef]

5. Machairaki, V. Human Pluripotent Stem Cells as In Vitro Models of Neurodegenerative Diseases. Adv. Exp. Med. Biol. 2020, 1195, 93-94. [CrossRef] [PubMed]

6. Lancaster, M.A.; Renner, M.; Martin, C.-A.; Wenzel, D.; Bicknell, L.S.; Hurles, M.E.; Homfray, T.; Penninger, J.M.; Jackson, A.P.; Knoblich, J.A. Cerebral organoids model human brain development and microcephaly. Nat. Cell Biol. 2013, 501, 373-379. [CrossRef] [PubMed]

7. McCauley, H.A.; Wells, J.M. Pluripotent stem cell-derived organoids: Using principles of developmental biology to grow human tissues in a dish. Development 2017, 144, 958-962. [CrossRef] [PubMed]

8. Doernberg, E.; Hollander, E. Neurodevelopmental Disorders (ASD and ADHD): DSM-5, ICD-10, and ICD-11. CNS Spectrums 2016, 21, 295-299. [CrossRef] [PubMed]

9. Lord, C.; Brugha, T.S.; Charman, T.; Cusack, J.; Dumas, G.; Frazier, T.; Jones, E.J.H.; Jones, R.M.; Pickles, A.; State, M.W.; et al. Autism spectrum disorder. Nat. Rev. Dis. Prim. 2020, 6, 1-23. [CrossRef]

10. Liu, X.; Campanac, E.; Cheung, H.-H.; Ziats, M.N.; Canterel-Thouennon, L.; Raygada, M.; Baxendale, V.; Pang, A.L.-Y.; Yang, L.; Swedo, S.; et al. Idiopathic Autism: Cellular and Molecular Phenotypes in Pluripotent Stem Cell-Derived Neurons. Mol. Neurobiol. 2017, 54, 4507-4523. [CrossRef] [PubMed]

11. Huguet, G.; Ey, E.; Bourgeron, T. The Genetic Landscapes of Autism Spectrum Disorders. Annu. Rev. Genom. Hum. Genet. 2013, 14, 191-213. [CrossRef] [PubMed]

12. Hyman, S.L.; Levy, S.E.; Myers, S.M.; Council on Children with Disabilities, Section on Developmental and Behavioral Pediatrics. Identification, Evaluation, and Management of Children with Autism Spectrum Disorder. Pediatrics 2019, 145 , e20193447. [CrossRef]

13. Bai, D.; Yip, B.H.K.; Windham, G.C.; Sourander, A.; Francis, R.; Yoffe, R.; Glasson, E.; Mahjani, B.; Suominen, A.; Leonard, H.; et al. Association of Genetic and Environmental Factors with Autism in a 5-Country Cohort. JAMA Psychiatry 2019, 76, 1035-1043. [CrossRef]

14. Gaugler, T.; Klei, L.; Sanders, S.J.; Bodea, C.A.; Goldberg, A.P.; Lee, A.B.; Mahajan, M.C.; Manaa, D.; Pawitan, Y.; Reichert, J.G.; et al. Most genetic risk for autism resides with common variation. Nat. Genet. 2014, 46, 881-885. [CrossRef]

15. Tick, B.; Bolton, P.; Happé, F.; Rutter, M.; Rijsdijk, F. Heritability of autism spectrum disorders: A meta-analysis of twin studies. J. Child Psychol. Psychiatry 2016, 57, 585-595. [CrossRef] [PubMed]

16. Ziats, M.N.; Rennert, O.M. The Evolving Diagnostic and Genetic Landscapes of Autism Spectrum Disorder. Front. Genet. 2016, 7, 65. [CrossRef] [PubMed]

17. Persico, A.M.; Napolioni, V. Autism genetics. Behav. Brain Res. 2013, 251, 95-112. [CrossRef] [PubMed]

18. Bury, L.A.; Wynshaw-Boris, A. Modeling Non-Syndromic Autism with Human-Induced Pluripotent Stem Cells. Neuropsychopharmacology 2017, 43, 219-220. [CrossRef] [PubMed]

19. De La Torre-Ubieta, L.; Won, H.; Stein, J.L.; Geschwind, D.H. Advancing the understanding of autism disease mechanisms through genetics. Nat. Med. 2016, 22, 345-361. [CrossRef]

20. Iossifov, I.; O’Roak, B.J.; Sanders, S.J.; Ronemus, M.; Krumm, N.; Levy, D.; Stessman, H.A.; Witherspoon, K.T.; Vives, L.; Patterson, K.E.; et al. The contribution of de novo coding mutations to autism spectrum disorder. Nat. Cell Biol. 2014, 515, $216-221$. [CrossRef]

21. Bourgeron, T. From the genetic architecture to synaptic plasticity in autism spectrum disorder. Nat. Rev. Neurosci. 2015, 16, 551-563. [CrossRef] [PubMed]

22. Li, J.; Lin, X.; Wang, M.; Hu, Y.; Xue, K.; Gu, S.; Lv, L.; Huang, S.; Xie, W. Potential role of genomic imprinted genes and brain developmental related genes in autism. BMC Med Genom. 2020, 13, 54. [CrossRef] [PubMed]

23. Ebert, D.H.; Greenberg, M.E. Activity-dependent neuronal signalling and autism spectrum disorder. Nat. Cell Biol. 2013, 493, 327-337. [CrossRef]

24. Gilbert, J.; Man, H.-Y. Fundamental Elements in Autism: From Neurogenesis and Neurite Growth to Synaptic Plasticity. Front. Cell. Neurosci. 2017, 11, 359. [CrossRef]

25. Tordjman, S.; Somogyi, E.; Coulon, N.; Kermarrec, S.; Cohen, D.; Bronsard, G.; Bonnot, O.; Weismann-Arcache, C.; Botbol, M.; Lauth, B.; et al. Geneâ€\% Ã $-\hat{a} € \%$ Environment Interactions in Autism Spectrum Disorders: Role of Epigenetic Mechanisms. Front. Psychiatry 2014, 5, 53. [CrossRef] 
26. Cheroni, C.; Caporale, N.; Testa, G. Autism spectrum disorder at the crossroad between genes and environment: Contributions, convergences, and interactions in ASD developmental pathophysiology. Mol. Autism 2020, 11, 1-18. [CrossRef] [PubMed]

27. Karahmadi, M.; Karimi, P.; Kamali, E.; Mousavi, S.M. Environmental factors influencing the risk of autism. J. Res. Med Sci. 2017, 22, 27. [CrossRef]

28. Hallmayer, J. Genetic Heritability and Shared Environmental Factors Among Twin Pairs with Autism. Arch. Gen. Psychiatry 2011, 68, 1095-1102. [CrossRef] [PubMed]

29. Bastaki, K.N.; Alwan, S.; Zahir, F.R. Maternal Prenatal Exposures in Pregnancy and Autism Spectrum Disorder: An Insight into the Epigenetics of Drugs and Diet as Key Environmental Influences. Adv. Neurobiol. 2020, 24, 143-162. [CrossRef]

30. Brito, A.; Russo, F.B.; Muotri, A.R.; Beltrão-Braga, P.C.B. Autism spectrum disorders and disease modeling using stem cells. Cell Tissue Res. 2018, 371, 153-160. [CrossRef]

31. Russo, F.B.; Freitas, B.C.; Pignatari, G.C.; Fernandes, I.R.; Sebat, J.; Muotri, A.R.; Beltrão-Braga, P.C.B. Modeling the Interplay Between Neurons and Astrocytes in Autism Using Human Induced Pluripotent Stem Cells. Biol. Psychiatry 2018, 83, 569-578. [CrossRef]

32. Suzuki, I.K.; Vanderhaeghen, P. Is this a brain which I see before me? Modeling human neural development with pluripotent stem cells. Development 2015, 142, 3138-3150. [CrossRef] [PubMed]

33. Ho, S.-M.; Topol, A.; Brennand, K.J. From “Directed Differentiation" to "Neuronal Induction": Modeling Neuropsychiatric Disease. Biomark. Insights 2015, 10, BMI.S20066-41. [CrossRef]

34. Sacco, R.; Cacci, E.; Novarino, G. Neural stem cells in neuropsychiatric disorders. Curr. Opin. Neurobiol. 2018, 48, 131-138. [CrossRef] [PubMed]

35. Marchetto, M.C.; Belinson, H.; Tian, Y.; Freitas, B.C.; Fu, C.; Vadodaria, K.; Beltrao-Braga, P.; Trujillo, C.A.; Mendes, A.P.; Padmanabhan, K.; et al. Altered proliferation and networks in neural cells derived from idiopathic autistic individuals. Mol. Psychiatry 2017, 22, 820-835. [CrossRef]

36. Wang, M.; Wei, P.-C.; Lim, C.K.; Gallina, I.S.; Marshall, S.; Marchetto, M.C.; Alt, F.W.; Gage, F.H. Increased Neural Progenitor Proliferation in a hiPSC Model of Autism Induces Replication Stress-Associated Genome Instability. Cell Stem Cell 2020, 26, 221-233.e6. [CrossRef]

37. Sánchez-Sánchez, S.M.; Magdalon, J.; Griesi-Oliveira, K.; Yamamoto, G.L.; Santacruz-Perez, C.; Fogo, M.; Passos-Bueno, M.R.; Sertié, A.L. Rare RELN variants affect Reelin-DAB1 signal transduction in autism spectrum disorder. Hum. Mutat. 2018, 39, 1372-1383. [CrossRef]

38. Griesi-Oliveira, K.; Acab, A.; Gupta, A.R.; Sunaga, D.Y.; Chailangkarn, T.; Nicol, X.; Nunez, Y.; Walker, M.F.; Murdoch, J.D.; Sanders, S.J.; et al. Modeling non-syndromic autism and the impact of TRPC6 disruption in human neurons. Mol. Psychiatry 2015, 20, 1350-1365. [CrossRef] [PubMed]

39. Marchetto, M.C.N.; Carromeu, C.; Acab, A.; Yu, D.; Yeo, G.W.; Mu, Y.; Chen, G.; Gage, F.H.; Muotri, A.R. A Model for Neural Development and Treatment of Rett Syndrome Using Human Induced Pluripotent Stem Cells. Cell 2010, 143, 527-539. [CrossRef]

40. Muotri, A.R.; Marchetto, M.C.N.; Coufal, N.G.; Oefner, R.; Yeo, G.; Nakashima, K.; Gage, F.H. L1 retrotransposition in neurons is modulated by MeCP2. Nat. Cell Biol. 2010, 468, 443-446. [CrossRef] [PubMed]

41. Nageshappa, S.; Carromeu, C.; Trujillo, C.A.; Mesci, P.; Espuny-Camacho, I.; Pasciuto, E.; Vanderhaeghen, P.; Verfaillie, C.M.; Raitano, S.; Kumar, A.; et al. Altered neuronal network and rescue in a human MECP2 duplication model. Mol. Psychiatry 2016, 21, 178-188. [CrossRef]

42. Rodrigues, D.C.; Mufteev, M.; Weatheritt, R.J.; Djuric, U.; Ha, K.C.; Ross, P.J.; Wei, W.; Piekna, A.; Sartori, M.A.; Byres, L.; et al. Shifts in Ribosome Engagement Impact Key Gene Sets in Neurodevelopment and Ubiquitination in Rett Syndrome. Cell Rep. 2020, 30, 4179-4196.e11. [CrossRef] [PubMed]

43. Telias, M.; Segal, M.; Ben-Yosef, D. Neural differentiation of fragile X human embryonic stem cells reveals abnormal patterns of development despite successful neurogenesis. Dev. Biol. 2013, 374, 32-45. [CrossRef] [PubMed]

44. Achuta, V.S.; Möykkynen, T.; Peteri, U.-K.; Turconi, G.; Rivera, C.; Keinänen, K.; Castrén, M.L. Functional changes of AMPA responses in human induced pluripotent stem cell-derived neural progenitors in fragile X syndrome. Sci. Signal. 2018, 11, eaan8784. [CrossRef] [PubMed]

45. Zucco, A.J.; Pozzo, V.D.; Afinogenova, A.; Hart, R.P.; Devinsky, O.; D’Arcangelo, G. Neural progenitors derived from Tuberous Sclerosis Complex patients exhibit attenuated PI3K/AKT signaling and delayed neuronal differentiation. Mol. Cell. Neurosci. 2018, 92, 149-163. [CrossRef]

46. Martin, P.; Wagh, V.; Reis, S.A.; Erdin, S.; Beauchamp, R.L.; Shaikh, G.; Talkowski, M.; Thiele, E.; Sheridan, S.D.; Haggarty, S.J.; et al. TSC patient-derived isogenic neural progenitor cells reveal altered early neurodevelopmental phenotypes and rapamycin-induced MNK-eIF4E signaling. Mol. Autism 2020, 11, 1-15. [CrossRef]

47. Breen, M.S.; Browne, A.; Hoffman, G.E.; Stathopoulos, S.; Brennand, K.; Buxbaum, J.D.; Drapeau, E. Transcriptional signatures of participant-derived neural progenitor cells and neurons implicate altered Wnt signaling in Phelan-McDermid syndrome and autism. Mol. Autism 2020, 11, 1-23. [CrossRef]

48. Paşca, S.P.; Portmann, T.; Voineagu, I.; Yazawa, M.; Shcheglovitov, A.; Paşca, A.M.; Cord, B.; Palmer, T.D.; Chikahisa, S.; Nishino, S.; et al. Using iPSC-derived neurons to uncover cellular phenotypes associated with Timothy syndrome. Nat. Med. 2011, 17, 1657-1662. [CrossRef] [PubMed] 
49. Tian, Y.; Voineagu, I.; Paşca, S.P.; Won, H.; Chandran, V.; Horvath, S.; E Dolmetsch, R.; Geschwind, D.H. Alteration in basal and depolarization induced transcriptional network in iPSC derived neurons from Timothy syndrome. Genome Med. $2014,6,75$. [CrossRef]

50. Moon, U.Y.; Park, J.Y.; Park, R.; Cho, J.Y.; Hughes, L.J.; McKenna, J.T.; Goetzl, L.; Cho, S.-H.; Crino, P.B.; Gambello, M.J.; et al. Impaired Reelin-Dab1 Signaling Contributes to Neuronal Migration Deficits of Tuberous Sclerosis Complex. Cell Rep. 2015, 12, 965-978. [CrossRef]

51. Vidal, S.; Xiol, C.; Pascual-Alonso, A.; O'Callaghan, M.; Pineda, M.; Armstrong, J. Genetic Landscape of Rett Syndrome Spectrum: Improvements and Challenges. Int. J. Mol. Sci. 2019, 20, 3925. [CrossRef] [PubMed]

52. Kyle, S.M.; Vashi, N.; Justice, M.J. Rett syndrome: A neurological disorder with metabolic components. Open Biol. 2018,8 , 170216. [CrossRef]

53. Banerjee, A.; Miller, M.T.; Li, K.; Sur, M.; E Kaufmann, W. Towards a better diagnosis and treatment of Rett syndrome: A model synaptic disorder. Brain 2019, 142, 239-248. [CrossRef]

54. Rajaratnam, A.; Potter, L.A.; Biag, H.M.B.; Schneider, A.; Petrasic, I.C.; Hagerman, R.J. Review of Autism Profiles and Response to Sertraline in Fragile X Syndrome-Associated Autism vs. Non-syndromic Autism; Next Steps for Targeted Treatment. Front. Neurol. 2020, 11, 581429. [CrossRef]

55. Sztainberg, Y.; Zoghbi, H.Y. Lessons learned from studying syndromic autism spectrum disorders. Nat. Neurosci. 2016, 19, 1408-1417. [CrossRef] [PubMed]

56. Volpi, A.; Sala, G.; Lesma, E.; Labriola, F.; Righetti, M.; Alfano, R.M.; Cozzolino, M. Tuberous sclerosis complex: New insights into clinical and therapeutic approach. J. Nephrol. 2018, 32, 355-363. [CrossRef]

57. Vogels, A.; Droogmans, G.; Vergaelen, E.; Van Buggenhout, G.; Swillen, A. Recent developments in Phelan-McDermid syndrome research: An update on cognitive development, communication and psychiatric disorders. Curr. Opin. Psychiatry 2021, 34, 118-122 [CrossRef] [PubMed]

58. Xu, N.; Lv, H.; Yang, T.; Du, X.; Sun, Y.; Xiao, B.; Fan, Y.; Luo, X.; Zhan, Y.; Wang, L.; et al. A 29 Mainland Chinese cohort of patients with Phelan-McDermid syndrome: Genotype-phenotype correlations and the role of SHANK3 haploinsufficiency in the important phenotypes. Orphanet J. Rare Dis. 2020, 15, 1-12. [CrossRef]

59. Bekdash, R.; Klein, A.D.; Yazawa, M. Timothy syndrome iPSC modeling. Mol. Cell. Neurosci. 2020, 107, 103529. [CrossRef]

60. Arai, Y.; Taverna, E. Neural Progenitor Cell Polarity and Cortical Development. Front. Cell. Neurosci. 2017, 11, 384. [CrossRef]

61. Sajdel-Sulkowska, E.M.; Xu, M.; McGinnis, W.; Koibuchi, N. Brain Region-Specific Changes in Oxidative Stress and Neurotrophin Levels in Autism Spectrum Disorders (ASD). Cerebellum 2010, 10, 43-48. [CrossRef] [PubMed]

62. Ameis, S.H.; Catani, M. Altered white matter connectivity as a neural substrate for social impairment in Autism Spectrum Disorder. Cortex 2015, 62, 158-181. [CrossRef]

63. Armstrong, D.D.; Dunn, K.; Antalffy, B. Decreased dendritic branching in frontal, motor and limbic cortex in Rett syndrome compared with trisomy 21. J. Neuropathol. Exp. Neurol. 1998, 57, 1013-1017. [CrossRef]

64. Belichenko, P.V.; Hagberg, B.; Dahlström, A. Morphological study of neocortical areas in Rett syndrome. Acta Neuropathol. 1997, 93, 50-61. [CrossRef]

65. Hensch, T.K. Critical period plasticity in local cortical circuits. Nat. Rev. Neurosci. 2005, 6, 877-888. [CrossRef]

66. Rubenstein, J.L. Three hypotheses for developmental defects that may underlie some forms of autism spectrum disorder. Curr. Opin. Neurol. 2010, 23, 118-123. [CrossRef] [PubMed]

67. Uzunova, G.; Pallanti, S.; Hollander, E. Excitatory/inhibitory imbalance in autism spectrum disorders: Implications for interventions and therapeutics. World J. Biol. Psychiatry 2015, 17, 1-13. [CrossRef] [PubMed]

68. Griesi-Oliveira, K.; Fogo, M.S.; Pinto, B.G.G.; Alves, A.Y.; Suzuki, A.M.; Morales, A.G.; Ezquina, S.; Sosa, O.J.; Sutton, G.J.; Sunaga-Franze, D.Y.; et al. Transcriptome of iPSC-derived neuronal cells reveals a module of co-expressed genes consistently associated with autism spectrum disorder. Mol. Psychiatry 2020, 1-17. [CrossRef]

69. Mariani, J.; Coppola, G.; Zhang, P.; Abyzov, A.; Provini, L.; Tomasini, L.; Amenduni, M.; Szekely, A.; Palejev, D.; Wilson, M.; et al. FOXG1-Dependent Dysregulation of GABA/Glutamate Neuron Differentiation in Autism Spectrum Disorders. Cell 2015, 162, 375-390. [CrossRef]

70. Zaslavsky, K.; Zhang, W.-B.; McCready, F.P.; Rodrigues, D.C.; Deneault, E.; Loo, C.; Zhao, M.; Ross, P.J.; El Hajjar, J.; Romm, A.; et al. SHANK2 mutations associated with autism spectrum disorder cause hyperconnectivity of human neurons. Nat. Neurosci. 2019, 22, 556-564. [CrossRef] [PubMed]

71. Landucci, E.; Brindisi, M.; Bianciardi, L.; Catania, L.M.; Daga, S.; Croci, S.; Frullanti, E.; Fallerini, C.; Butini, S.; Brogi, S.; et al. iPSC-derived neurons profiling reveals GABAergic circuit disruption and acetylated $\alpha$-tubulin defect which improves after iHDAC6 treatment in Rett syndrome. Exp. Cell Res. 2018, 368, 225-235. [CrossRef] [PubMed]

72. Amenduni, M.; De Filippis, R.; Cheung, A.Y.L.; Disciglio, V.; Epistolato, M.C.; Ariani, F.; Mari, F.; Mencarelli, M.A.; Hayek, Y.; Renieri, A.; et al. iPS cells to model CDKL5-related disorders. Eur. J. Hum. Genet. 2011, 19, 1246-1255. [CrossRef]

73. Yennawar, M.; White, R.S.; Jensen, F.E. AMPA Receptor Dysregulation and Therapeutic Interventions in a Mouse Model of CDKL5 Deficiency Disorder. J. Neurosci. 2019, 39, 4814-4828. [CrossRef]

74. Mackay, C.I.; Wong, K.; Demarest, S.T.; Benke, T.A.; Downs, J.; Leonard, H. Exploring genotype-phenotype relationships in the CDKL5 deficiency disorder using an international dataset. Clin. Genet. 2021, 99, 157-165. [CrossRef] 
75. Ricciardi, S.; Ungaro, F.; Hambrock, M.; Rademacher, N.; Stefanelli, G.; Brambilla, D.; Sessa, A.; Magagnotti, C.; Bachi, A.; Giarda, E.; et al. CDKL5 ensures excitatory synapse stability by reinforcing NGL-1-PSD95 interaction in the postsynaptic compartment and is impaired in patient iPSC-derived neurons. Nat. Cell Biol. 2012, 14, 911-923. [CrossRef] [PubMed]

76. Sheridan, S.D.; Theriault, K.M.; Reis, S.A.; Zhou, F.; Madison, J.M.; Daheron, L.; Loring, J.F.; Haggarty, S.J. Epigenetic Characterization of the FMR1 Gene and Aberrant Neurodevelopment in Human Induced Pluripotent Stem Cell Models of Fragile X Syndrome. PLoS ONE 2011, 6, e26203. [CrossRef]

77. Halevy, T.; Czech, C.; Benvenisty, N. Molecular Mechanisms Regulating the Defects in Fragile X Syndrome Neurons Derived from Human Pluripotent Stem Cells. Stem Cell Rep. 2015, 4, 37-46. [CrossRef] [PubMed]

78. Lu, P.; Chen, X.; Feng, Y.; Zeng, Q.; Jiang, C.; Zhu, X.; Fan, G.; Xue, Z. Integrated transcriptome analysis of human iPS cells derived from a fragile $X$ syndrome patient during neuronal differentiation. Sci. China Life Sci. 2016, 59, 1093-1105. [CrossRef]

79. Boland, M.J.; Nazor, K.L.; Tran, H.T.; Szücs, A.; Lynch, C.L.; Paredes, R.; Tassone, F.; Sanna, P.P.; Hagerman, R.J.; Loring, J.F. Molecular analyses of neurogenic defects in a human pluripotent stem cell model of fragile X syndrome. Brain 2017, 140, 582-598. [CrossRef]

80. Utami, K.H.; Skotte, N.H.; Colaço, A.R.; Yusof, N.A.B.M.; Sim, B.; Yeo, X.Y.; Bae, H.-G.; Garcia-Miralles, M.; Radulescu, C.I.; Chen, Q.; et al. Integrative Analysis Identifies Key Molecular Signatures Underlying Neurodevelopmental Deficits in Fragile X Syndrome. Biol. Psychiatry 2020, 88, 500-511. [CrossRef]

81. Doers, M.E.; Musser, M.T.; Nichol, R.; Berndt, E.R.; Baker, M.; Gomez, T.M.; Zhang, S.-C.; Abbeduto, L.; Bhattacharyya, A. iPSCDerived Forebrain Neurons from FXS Individuals Show Defects in Initial Neurite Outgrowth. Stem Cells Dev. 2014, 23, 1777-1787. [CrossRef]

82. Liu, J.; Kościelska, K.A.; Cao, Z.; Hulsizer, S.; Grace, N.; Mitchell, G.; Nacey, C.; Githinji, J.; McGee, J.; Garcia-Arocena, D.; et al. Signaling defects in iPSC-derived fragile X premutation neurons. Hum. Mol. Genet. 2012, 21, 3795-3805. [CrossRef]

83. Li, Y.; Cao, J.; Chen, M.; Li, J.; Sun, Y.; Zhang, Y.; Zhu, Y.; Wang, L.; Zhang, C. Abnormal Neural Progenitor Cells Differentiated from Induced Pluripotent Stem Cells Partially Mimicked Development of TSC2 Neurological Abnormalities. Stem Cell Rep. 2017, 8, 883-893. [CrossRef]

84. Nadadhur, A.G.; Alsaqati, M.; Gasparotto, L.; Cornelissen-Steijger, P.; Van Hugte, E.; Dooves, S.; Harwood, A.J.; Heine, V.M. Neuron-Glia Interactions Increase Neuronal Phenotypes in Tuberous Sclerosis Complex Patient iPSC-Derived Models. Stem Cell Rep. 2019, 12, 42-56. [CrossRef]

85. Bateup, H.S.; Johnson, C.A.; Denefrio, C.L.; Saulnier, J.L.; Kornacker, K.; Sabatini, B.L. Excitatory/Inhibitory Synaptic Imbalance Leads to Hippocampal Hyperexcitability in Mouse Models of Tuberous Sclerosis. Neuron 2013, 78, 510-522. [CrossRef]

86. Winden, K.D.; Sundberg, M.; Yang, C.; Wafa, S.M.; Dwyer, S.; Chen, P.-F.; Buttermore, E.D.; Sahin, M. Biallelic Mutations in TSC2 Lead to Abnormalities Associated with Cortical Tubers in Human iPSC-Derived Neurons. J. Neurosci. 2019, 39, 9294-9305. [CrossRef]

87. Shcheglovitov, A.; Shcheglovitova, O.; Yazawa, M.; Portmann, T.; Shu, R.; Sebastiano, V.; Krawisz, A.; Froehlich, W.; Bernstein, J.A.; Hallmayer, J.F.; et al. SHANK3 and IGF1 restore synaptic deficits in neurons from 22q13 deletion syndrome patients. Nat. Cell Biol. 2013, 503, 267-271. [CrossRef] [PubMed]

88. Darville, H.; Poulet, A.; Rodet-Amsellem, F.; Chatrousse, L.; Pernelle, J.; Boissart, C.; Héron, D.; Nava, C.; Perrier, A.; Jarrige, M.; et al. Human Pluripotent Stem Cell-derived Cortical Neurons for High Throughput Medication Screening in Autism: A Proof of Concept Study in SHANK3 Haploinsufficiency Syndrome. EBioMedicine 2016, 9, 293-305. [CrossRef]

89. Gouder, L.; Vitrac, A.; Goubran-Botros, H.; Danckaert, A.; Tinevez, J.-Y.; André-Leroux, G.; Atanasova, E.; Lemière, N.; Biton, A.; Leblond, C.S.; et al. Altered spinogenesis in iPSC-derived cortical neurons from patients with autism carrying de novo SHANK3 mutations. Sci. Rep. 2019, 9, 94. [CrossRef] [PubMed]

90. Yi, F.; Danko, T.; Botelho, S.C.; Patzke, C.; Pak, C.; Wernig, M.; Südhof, T.C. Autism-associated SHANK3 haploinsufficiency causes Ih channelopathy in human neurons. Science 2016, 352, aaf2669. [CrossRef]

91. Krey, J.F.; Pasca, S.P.; Shcheglovitov, A.; Yazawa, M.; Schwemberger, R.; Rasmusson, R.L.; Dolmetsch, R.E. Timothy syndrome is associated with activity-dependent dendritic retraction in rodent and human neurons. Nat. Neurosci. 2013, 16, 201-209. [CrossRef] [PubMed]

92. Panagiotakos, G.; Haveles, C.; Arjun, A.; Petrova, R.; Rana, A.; Portmann, T.; Paşca, S.P.; Palmer, T.D.; E Dolmetsch, R. Aberrant calcium channel splicing drives defects in cortical differentiation in Timothy syndrome. eLife 2019, 8, 51037. [CrossRef] [PubMed]

93. Chamberlain, S.J.; Chen, P.-F.; Ng, K.Y.; Bourgois-Rocha, F.; Lemtiri-Chlieh, F.; Levine, E.S.; Lalande, M. Induced pluripotent stem cell models of the genomic imprinting disorders Angelman and Prader-Willi syndromes. Proc. Natl. Acad. Sci. USA 2010, 107, 17668-17673. [CrossRef] [PubMed]

94. Madaan, M.; Mendez, M.D. Angelman Syndrome. In StatPearls [Internet]; StatPearls Publishing: Treasure Island, FL, USA, 2020.

95. Khatri, N.; Man, H.-Y. The Autism and Angelman Syndrome Protein Ube3A/E6AP: The Gene, E3 Ligase Ubiquitination Targets and Neurobiological Functions. Front. Mol. Neurosci. 2019, 12, 109. [CrossRef]

96. Stanurova, J.; Neureiter, A.; Hiber, M.; Kessler, H.D.O.; Stolp, K.; Goetzke, R.; Klein, D.; Bankfalvi, A.; Klump, H.; Steenpass, L. Angelman syndrome-derived neurons display late onset of paternal UBE3A silencing. Sci. Rep. 2016, 6, 30792. [CrossRef]

97. Fink, J.J.; Robinson, T.M.; Germain, N.D.; Sirois, C.L.; Bolduc, K.A.; Ward, A.J.; Rigo, F.; Chamberlain, S.J.; Levine, E.S. Disrupted neuronal maturation in Angelman syndrome-derived induced pluripotent stem cells. Nat. Commun. 2017, 8, 15038. [CrossRef] 
98. Siracusa, R.; Fusco, R.; Cuzzocrea, S. Astrocytes: Role and Functions in Brain Pathologies. Front. Pharmacol. 2019, 10, 1114. [CrossRef] [PubMed]

99. Edmonson, C.; Ziats, M.N.; Rennert, O.M. Altered glial marker expression in autistic post-mortem prefrontal cortex and cerebellum. Mol. Autism 2014, 5, 3. [CrossRef] [PubMed]

100. Martínez-Cerdeño, V. Dendrite and spine modifications in autism and related neurodevelopmental disorders in patients and animal models. Dev. Neurobiol. 2017, 77, 393-404. [CrossRef]

101. Vargas, D.L.; Nascimbene, C.; Krishnan, C.; Zimmerman, A.W.; Pardo, C.A. Neuroglial activation and neuroinflammation in the brain of patients with autism. Ann. Neurol. 2004, 57, 67-81. [CrossRef] [PubMed]

102. Saghazadeh, A.; Ataeinia, B.; Keynejad, K.; Abdolalizadeh, A.; Hirbod-Mobarakeh, A.; Rezaei, N. A meta-analysis of proinflammatory cytokines in autism spectrum disorders: Effects of age, gender, and latitude. J. Psychiatr. Res. 2019, 115, 90-102. [CrossRef]

103. Malik, M.; Sheikh, A.M.; Wen, G.G.; Spivack, W.; Brown, W.T.; Li, X. Expression of inflammatory cytokines, Bcl2 and cathepsin D are altered in lymphoblasts of autistic subjects. Immunobiology 2011, 216, 80-85. [CrossRef]

104. Enstrom, A.M.; Onore, C.E.; Van De Water, J.A.; Ashwood, P. Differential monocyte responses to TLR ligands in children with autism spectrum disorders. Brain, Behav. Immun. 2010, 24, 64-71. [CrossRef]

105. Williams, E.C.; Zhong, X.; Mohamed, A.; Li, R.; Liu, Y.; Dong, Q.; Ananiev, G.E.; Mok, J.C.C.; Lin, B.R.; Lu, J.; et al. Mutant astrocytes differentiated from Rett syndrome patients-specific iPSCs have adverse effects on wild-type neurons. Hum. Mol. Genet. 2014, 23, 2968-2980. [CrossRef] [PubMed]

106. Kim, J.J.; Savas, J.N.; Miller, M.T.; Hu, X.; Carromeu, C.; Lavallée-Adam, M.; Freitas, B.C.G.; Muotri, A.R.; Yates, J.R.; Ghosh, A. Proteomic analyses reveal misregulation of LIN28 expression and delayed timing of glial differentiation in human iPS cells with MECP2 loss-of-function. PLoS ONE 2019, 14, e0212553. [CrossRef] [PubMed]

107. Yamazaki, Y. Oligodendrocyte Physiology Modulating Axonal Excitability and Nerve Conduction. Adv. Exp. Med. Biol. 2019, 1190, 123-144. [CrossRef]

108. Zheng, W.; Li, Q.; Zhao, C.; Da, Y.; Zhang, H.-L.; Chen, Z. Differentiation of Glial Cells From hiPSCs: Potential Applications in Neurological Diseases and Cell Replacement Therapy. Front. Cell. Neurosci. 2018, 12, 239. [CrossRef]

109. Bronzuoli, M.R.; Facchinetti, R.; Ingrassia, D.; Sarvadio, M.; Schiavi, S.; Steardo, L.; Verkhratsky, A.; Trezza, V.; Scuderi, C. Neuroglia in the autistic brain: Evidence from a preclinical model. Mol. Autism 2018, 9, 1-17. [CrossRef]

110. Corrigan, N.M.; Shaw, D.W.W.; Estes, A.M.; Richards, T.L.; Munson, J.; Friedman, S.D.; Dawson, G.; Artru, A.A.; Dager, S.R. Atypical Developmental Patterns of Brain Chemistry in Children with Autism Spectrum Disorder. JAMA Psychiatry 2013, 70, 964-974. [CrossRef]

111. Kleinhans, N.M.; Schweinsburg, B.C.; Cohen, D.N.; Müller, R.-A.; Courchesne, E. N-acetyl aspartate in autism spectrum disorders: Regional effects and relationship to fMRI activation. Brain Res. 2007, 1162, 85-97. [CrossRef]

112. Cheli, V.T.; González, D.A.S.; Zamora, N.N.; Lama, T.N.; Spreuer, V.; Rasmusson, R.L.; Bett, G.C.; Panagiotakos, G.; Paez, P.M. Enhanced oligodendrocyte maturation and myelination in a mouse model of Timothy syndrome. Glia 2018, 66, 2324-2339. [CrossRef] [PubMed]

113. Musunuru, K.; Sheikh, F.; Gupta, R.M.; Houser, S.R.; Maher, K.O.; Milan, D.J.; Terzic, A.; Wu, J.C. Induced Pluripotent Stem Cells for Cardiovascular Disease Modeling and Precision Medicine: A Scientific Statement from the American Heart Association. Circ. Genom. Precis. Med. 2018, 11, e000043. [CrossRef] [PubMed]

114. Noguchi, H.; Miyagi-Shiohira, C.; Nakashima, Y. Induced Tissue-Specific Stem Cells and Epigenetic Memory in Induced Pluripotent Stem Cells. Int. J. Mol. Sci. 2018, 19, 930. [CrossRef]

115. Ilieva, M.; Fex-Svenningsen, A.; Thorsen, M.; Michel, T.M. Psychiatry in a Dish: Stem Cells and Brain Organoids Modeling Autism Spectrum Disorders. Biol. Psychiatry 2018, 83, 558-568. [CrossRef] [PubMed]

116. Hu, B.-Y.; Weick, J.P.; Yu, J.; Ma, L.-X.; Zhang, X.-Q.; Thomson, J.A.; Zhang, S.-C. Neural differentiation of human induced pluripotent stem cells follows developmental principles but with variable potency. Proc. Natl. Acad. Sci. USA 2010, 107, 4335-4340. [CrossRef]

117. Sasai, Y. Next-Generation Regenerative Medicine: Organogenesis from Stem Cells in 3D Culture. Cell Stem Cell 2013, 12, 520-530. [CrossRef]

118. Paşca, A.M.; A Sloan, S.; E Clarke, L.; Tian, Y.; Makinson, C.D.; Huber, N.; Kim, C.H.; Park, J.-Y.; A O’Rourke, N.; Nguyen, K.D.; et al. Functional cortical neurons and astrocytes from human pluripotent stem cells in 3D culture. Nat. Methods 2015, 12, 671-678. [CrossRef] [PubMed]

119. Sloan, S.A.; Darmanis, S.; Huber, N.; Khan, T.A.; Birey, F.; Caneda, C.; Reimer, R.; Quake, S.R.; Barres, B.A.; Paşca, S.P. Human Astrocyte Maturation Captured in 3D Cerebral Cortical Spheroids Derived from Pluripotent Stem Cells. Neuron 2017, 95, 779-790.e6. [CrossRef] [PubMed]

120. Marton, R.M.; Miura, Y.; Sloan, S.A.; Li, Q.; Revah, O.; Levy, R.J.; Huguenard, J.R.; Pașca, S.P. Differentiation and maturation of oligodendrocytes in human three-dimensional neural cultures. Nat. Neurosci. 2019, 22, 484-491. [CrossRef] [PubMed]

121. Schafer, S.T.; Paquola, A.C.M.; Stern, S.; Gosselin, D.; Ku, M.; Pena, M.; Kuret, T.J.M.; Liyanage, M.; Mansour, A.A.; Jaeger, B.N.; et al. Pathological priming causes developmental gene network heterochronicity in autistic subject-derived neurons. Nat. Neurosci. 2019, 22, 243-255. [CrossRef] 
122. Wang, P.; Mokhtari, R.; Pedrosa, E.; Kirschenbaum, M.; Bayrak, C.; Zheng, D.; Lachman, H.M. CRISPR/Cas9-mediated heterozygous knockout of the autism gene CHD8 and characterization of its transcriptional networks in cerebral organoids derived from iPS cells. Mol. Autism 2017, 8, 1-17. [CrossRef]

123. Mellios, N.; Feldman, D.A.; Sheridan, S.D.; Ip, J.P.; Kwok, S.; Amoah, S.K.; Rosen, B.; Rodriguez, B.A.; Crawford, B.; Swaminathan, R.; et al. MeCP2-regulated miRNAs control early human neurogenesis through differential effects on ERK and AKT signaling. Mol. Psychiatry 2018, 23, 1051-1065. [CrossRef]

124. Xiang, Y.; Tanaka, Y.; Patterson, B.; Hwang, S.-M.; Hysolli, E.; Cakir, B.; Kim, K.-Y.; Wang, W.; Kang, Y.-J.; Clement, E.M.; et al. Dysregulation of BRD4 Function Underlies the Functional Abnormalities of MeCP2 Mutant Neurons. Mol. Cell 2020, 79, 84-98.e9. [CrossRef]

125. Blair, J.D.; Hockemeyer, D.; Bateup, H.S. Genetically engineered human cortical spheroid models of tuberous sclerosis. Nat. Med. 2018, 24, 1568-1578. [CrossRef]

126. Niu, W.; Parent, J.M. Modeling genetic epilepsies in a dish. Dev. Dyn. 2020, 249, 56-75. [CrossRef] [PubMed]

127. Birey, F.; Andersen, J.; Makinson, C.D.; Islam, S.; Wei, W.; Huber, N.; Fan, H.C.; Metzler, K.R.C.; Panagiotakos, G.; Thom, N.; et al. Assembly of functionally integrated human forebrain spheroids. Nat. Cell Biol. 2017, 545, 54-59. [CrossRef]

128. Sun, A.X.; Yuan, Q.; Fukuda, M.; Yu, W.; Yan, H.; Lim, G.G.Y.; Nai, M.H.; D'Agostino, G.A.; Tran, H.-D.; Itahana, Y.; et al. Potassium channel dysfunction in human neuronal models of Angelman syndrome. Science 2019, 366, 1486-1492. [CrossRef] [PubMed]

129. Renner, M.; A Lancaster, M.; Bian, S.; Choi, H.; Ku, T.; Peer, A.; Chung, K.; A Knoblich, J. Self-organized developmental patterning and differentiation in cerebral organoids. EMBO J. 2017, 36, 1316-1329. [CrossRef] [PubMed]

130. Chan, W.K.; Griffiths, R.; Price, D.J.; Mason, J.O. Cerebral organoids as tools to identify the developmental roots of autism. Mol. Autism 2020, 11, 1-14. [CrossRef]

131. Hong, S.; Dissing-Olesen, L.; Stevens, B. New insights on the role of microglia in synaptic pruning in health and disease. Curr. Opin. Neurobiol. 2016, 36, 128-134. [CrossRef] [PubMed]

132. Tabuchi, K.; Blundell, J.; Etherton, M.R.; Hammer, R.E.; Liu, X.; Powell, C.M.; Südhof, T.C. A Neuroligin-3 Mutation Implicated in Autism Increases Inhibitory Synaptic Transmission in Mice. Science 2007, 318, 71-76. [CrossRef]

133. Basu, R.; Duan, X.; Taylor, M.R.; Martin, E.A.; Muralidhar, S.; Wang, Y.; Gangi-Wellman, L.; Das, S.C.; Yamagata, M.; West, P.J.; et al. Heterophilic Type II Cadherins Are Required for High-Magnitude Synaptic Potentiation in the Hippocampus. Neuron 2017, 96, 160-176.e8. [CrossRef] [PubMed]

134. Kolevzon, A.; Bush, L.; Wang, A.T.; Halpern, D.; Frank, Y.; Grodberg, D.; Rapaport, R.; Tavassoli, T.; Chaplin, W.; Soorya, L.; et al. A pilot controlled trial of insulin-like growth factor-1 in children with Phelan-McDermid syndrome. Mol. Autism 2014, 5, 54. [CrossRef] [PubMed]

135. Khwaja, O.S.; Ho, E.; Barnes, K.V.; O’Leary, H.M.; Pereira, L.M.; Finkelstein, Y.; Nelson, C.A.; Vogel-Farley, V.; DeGregorio, G.; Holm, I.A.; et al. Safety, pharmacokinetics, and preliminary assessment of efficacy of mecasermin (recombinant human IGF-1) for the treatment of Rett syndrome. Proc. Natl. Acad. Sci. USA 2014, 111, 4596-4601. [CrossRef]

136. Sadowski, K.; Kotulska, K.; Schwartz, R.A.; Jóźwiak, S. Systemic effects of treatment with mTOR inhibitors in tuberous sclerosis complex: A comprehensive review. J. Eur. Acad. Dermatol. Venereol. 2015, 30, 586-594. [CrossRef]

137. Russo, F.B.; Brito, A.; de Freitas, A.M.; Castanha, A.; de Freitas, B.C.; Beltrão-Braga, P.C.B. The use of iPSC technology for modeling Autism Spectrum Disorders. Neurobiol. Dis. 2019, 130, 104483. [CrossRef] [PubMed]

138. Brick, D.J.; Nethercott, H.E.; Montesano, S.; Banuelos, M.G.; Stover, A.E.; Schutte, S.S.; O’Dowd, D.K.; Hagerman, R.J.; Ono, M.Y.; Hessl, D.R.; et al. The Autism Spectrum Disorders Stem Cell Resource at Children's Hospital of Orange County: Implications for Disease Modeling and Drug Discovery. Stem Cells Transl. Med. 2014, 3, 1275-1286. [CrossRef]

139. Miller, J.C.; Tan, S.; Qiao, G.; A Barlow, K.; Wang, J.; Xiangdong, M.; Meng, X.; E Paschon, D.; Leung, E.; Hinkley, S.J.; et al. A TALE nuclease architecture for efficient genome editing. Nat. Biotechnol. 2010, 29, 143-148. [CrossRef] [PubMed]

140. Mali, P.; Yang, L.; Esvelt, K.M.; Aach, J.; Guell, M.; Dicarlo, J.E.; Norville, J.E.; Church, G.M. RNA-Guided Human Genome Engineering via Cas9. Sci. 2013, 339, 823-826. [CrossRef] [PubMed]

141. De La Vega, L.; Lee, C.; Sharma, R.; Amereh, M.; Willerth, S.M. 3D bioprinting models of neural tissues: The current state of the field and future directions. Brain Res. Bull. 2019, 150, 240-249. [CrossRef] [PubMed]

142. Salaris, F.; Rosa, A. Construction of 3D in vitro models by bioprinting human pluripotent stem cells: Challenges and opportunities. Brain Res. 2019, 1723, 146393. [CrossRef]

143. Mansour, A.A.; Gonçalves, J.T.; Bloyd, C.W.; Li, H.; Fernandes, S.; Quang, D.; Johnston, S.; Parylak, S.L.; Jin, X.; Gage, F.H. An in vivo model of functional and vascularized human brain organoids. Nat. Biotechnol. 2018, 36, 432-441. [CrossRef] [PubMed]

144. Takebe, T.; Enomura, M.; Yoshizawa, E.; Kimura, M.; Koike, H.; Ueno, Y.; Matsuzaki, T.; Yamazaki, T.; Toyohara, T.; Osafune, K.; et al. Vascularized and Complex Organ Buds from Diverse Tissues via Mesenchymal Cell-Driven Condensation. Cell Stem Cell 2015, 16, 556-565. [CrossRef] [PubMed]

145. Ham, O.; Jin, Y.B.; Kim, J.; Lee, M.-O. Blood vessel formation in cerebral organoids formed from human embryonic stem cells. Biochem. Biophys. Res. Commun. 2020, 521, 84-90. [CrossRef] [PubMed]

146. Qian, X.; Nguyen, H.N.; Song, M.M.; Hadiono, C.; Ogden, S.C.; Hammack, C.; Yao, B.; Hamersky, G.R.; Jacob, F.; Zhong, C.; et al. Brain-Region-Specific Organoids Using Mini-bioreactors for Modeling ZIKV Exposure. Cell 2016, 165, 1238-1254. [CrossRef] 